\title{
Sonography of Peripheral Lymph Nodes Part 2: Doppler Criteria and Typical Findings of Distinct Entities
}

Author

Affiliation

\author{
T. Rettenbacher
}

Radiology, Medical University Innsbruck

\section{VNR 2760512014144215091 \\ received $\quad 6.2 .2013$ \\ accepted 22.7.2013}

Bibliography

DOI http://dx.doi.org/

10.1055/s-0033-1355593

Published online:

December 12, 2013

Ultraschall in Med 2014; 35: 10 32 ㄷ Georg Thieme Verlag KG Stuttgart · New York .

ISSN 0172-4614

\section{Correspondence}

Prof. Thomas Rettenbacher

Radiology, Medical University Innsbruck

Anichstr. 35

6020 Innsbruck

Austria

Tel.: ++ 43/5 12/50424021

Fax: ++43/5 12/50424029

thomas.rettenbacher@

i-med.ac.at

\section{Learning objectives}

\section{$\nabla$}

Doppler sonographic criteria for assessing peripheral lymph nodes

Typical sonographic findings of distinct entities in the case of peripheral lymph node involvement

\section{Doppler sonographic criteria for assessing peripheral lymph nodes}

\section{Introduction}

B-mode criteria provide the foundation for the sonographic identification of peripheral lymph nodes as normal or pathological and for differential diagnosis. "Sonography of Peripheral Lymph Nodes Part 1: Normal Findings and B-Image Criteria" therefore provides a comprehensive description of the sonographic appearance of normal peripheral lymph nodes in the individual regions of the body and of the B-mode criteria of pathological peripheral lymph nodes [1]. Color/power Doppler and pulsed Doppler sonography is only of secondary importance for the evaluation of peripheral lymphadenopathy compared to B-mode sonography [2]. This requires equipment with high-quality Doppler (color/power Doppler, pulsed Doppler).

\section{Color and power Doppler}

In the case of lymph nodes, color and power Doppler is used to visualize individual vessels, the vascular tree, and the vascular architecture. Although the method can provide a clear overview of vessels, it must be taken into consideration that it requires a minimum vessel size, a favorable vessel course and a minimum blood flow velocity for vessel detection. Power Doppler is slightly more sensitive than color Doppler in many ultrasound units [3, 4]. However, color Doppler has the advantage of showing the blood flow direction and the relative average blood flow velocity. However, both methods can be alternatively used for vessel detection and to evaluate the vascular pattern.

Normal lymph node perfusion is the result of central vessels of the hilum, which branch into the lymph node periphery ( $\boldsymbol{O}$ Fig. 1 ). As a result, a uniform vascular tree emanating from the central region can be visualized with Doppler sonography [5-7]. This normal vascular tree can be preserved, changed, or destroyed in the case of lymphadenopathy ( $\bullet$ Fig. 1 ). Inflammatory processes and some malignant lymphomas typically result in enhancement of the normal vascular tree with increased perfusion ( $\bullet$ Fig. 3, 4, 8, 10), with this being most pronounced in the case of acute inflammatory processes, such as bacterial inflammation and Pfeiffer's disease ( 0 Fig. 3 ) [5, 8 , 9]. In contrast, malignant processes, particularly solid tumors, result in a change (ranging from asymmetry to destruction) of the normal vascular tree due to the nodular expansive growth $[6,9]$. Moreover, vascularization in the lymph node periphery increases in part due to vessels with extracapsular extension $[5,10]$. Therefore, changes ranging from asymmetry to destruction of the normal vascular tree, circumscribed negative areas on color/power Doppler sonography, hypervascularized areas, a spotted vascular pattern, peripheral vascularization enhancement and vessels with extracapsular extension are considered malignancy criteria on Doppler sonography ( $\boldsymbol{0}$ Fig. 1, 5, 6) [5, 10 - 12]. One limitation is that neoplastic processes can sometimes appear to have a normal vascular tree. Examples of this are malignant lymphomas such as chronic lymphocytic leukemia (CLL). On the other hand, non-neoplastic processes can result in significant changes in the vascular tree. A known example of this is tuberculosis, which frequently results in pronounced changes and necroses and thus in alteration of the vascular tree. It is also limiting that blood vessels often cannot be detected at all both in normal and pathological 


\section{Sonografie der peripheren Lymphknoten Teil 2: Doppler-Kriterien und typische Befunde bestimmter Entitäten}

\section{Lernziele}

$\nabla$

Dopplersonografische Kriterien zur Beurteilung der peripheren Lymphknoten.

Typische sonografische Befunde bestimmter Entitäten bei Befall der peripheren Lymphknoten.

\section{Dopplersonografische Kriterien zur Beurteilung peripherer Lymphknoten}

\section{Einleitung}

Die B-Bild-Kriterien sind die entscheidende Grundlage für das sonografische Erkennen der peripheren Lymphknoten als normal oder pathologisch und für die differenzialdiagnostische Eingrenzung. „Sonografie der peripheren Lymphknoten Teil 1: Normalbefunde und B-Bild-Kriterien " widmet sich deshalb ausführlich den sonografischen Erscheinungsbildern der normalen peripheren Lymphknoten in den einzelnen Körperregionen und den B-Bild-Kriterien pathologischer peripherer Lymphknoten [1]. Die Dopplersonografie in Form des Farb/Powerdopplers und des gepulsten Dopplers hat im Rahmen der Beurteilung einer peripheren Lymphadenopathie im Vergleich zur B-Bild-Sonografie nur ergänzende Bedeutung [2]. Dabei ist eine apparative Ausstattung mit hochwertigem Doppler (Farb/ Powerdoppler, gepulster Doppler) unverzichtbar.

\section{Farb- und Powerdoppler}

Der Farb- und Powerdoppler an Lymphknoten dient der Darstellung einzelner Gefäße, des Gefäßbaumes und der Gefäßarchitektur. Er weist übersichtlich Gefäße nach, wobei grundsätzlich zu bedenken ist, dass diese Methode zur Gefäßdetektion eine Gefäßmindestgröße, einen günstigen Gefäßverlauf und eine Blutflussmindestgeschwindigkeit benötigt. Der Powerdoppler ist bei vielen Ultraschallgeräten etwas sensitiver als der Farbdoppler [3, 4]. Der Farbdoppler bietet jedoch die Vorteile, dass er die Blutflussrichtung und die relative mittlere Blutflussgeschwindigkeit anzeigt. Beide Methoden können zum Gefäßnachweis und zur Beurteilung der Gefäßmuster jedoch alternativ verwendet werden.

Die normale Durchblutung eines Lymphknotens erfolgt über zentrale Gefäße des Hilus, die sich in die Lymphknotenperipherie aufzweigen ( $\bullet$ Abb. 1). Dadurch ist ein gleichmäßig aufgebauter, von zentral ausgehender Gefäßbaum dopplersonografisch nachzuweisen [5-7]. Dieser normale Gefäßbaum kann im Rahmen einer Lymphadenopathie erhalten oder verändert bis zerstört sein ( $\bullet \mathbf{A b b}$. 1). Entzündliche Prozesse und manche maligne Lymphome führen typischerweise zu einer Betonung des normalen Gefäßbaumes mit gesteigerter Durchblutung ( $\bullet$ Abb.3, 4, 8, 10), wobei diese bei akut entzündlichen Prozessen, wie zum Beispiel bei bakteriellen Entzündungen und bei Pfeiffer'schem Drüsenfieber, am ausgeprägtesten ist ( $\mathbf{A b b} . \mathbf{3}$ ) [5, 8, 9]. Im Gegensatz dazu führen maligne Prozesse, allen voran die soliden Tumoren, aufgrund des nodulär-verdrängenden Wachstums zu einer Veränderung (Asymmetrie bis Zerstörung) des normalen Gefäßbaumes [6, 9]. Außerdem nimmt die Vaskularisation in der Lymphknotenperipherie zum Teil durch kapselüberschreitende Gefäße zu $[5,10]$. Als dopplersonografische Malignitätskriterien gelten deshalb Asymmetrien bis hin zur Zerstörung des normalen Gefäßbaumes, umschriebene Aussparungen und hypervaskularisierte Areale, das gesprenkelte (spotted) Gefäßbild, die periphere Betonung der Vaskularisation und kapselüberschreitende Gefäße ( $\bullet$ Abb. 1, 5, 6) [5, 10 - 12].

Limitierend ist, dass einerseits neoplastische Prozesse manchmal einen normalen Gefäßbaumeindruck aufweisen können. Beispiele dafür sind maligne Lymphome wie etwa die chronische lymphatische Leukämie (CLL). Anderseits können nicht neoplastische Prozesse zu deutlichen Veränderungen am Gefäßbaum führen. Ein bekanntes Beispiel dazu ist die Tuberkulose, die regelmäßig zu ausgeprägten Veränderungen und Nekrosen und damit 


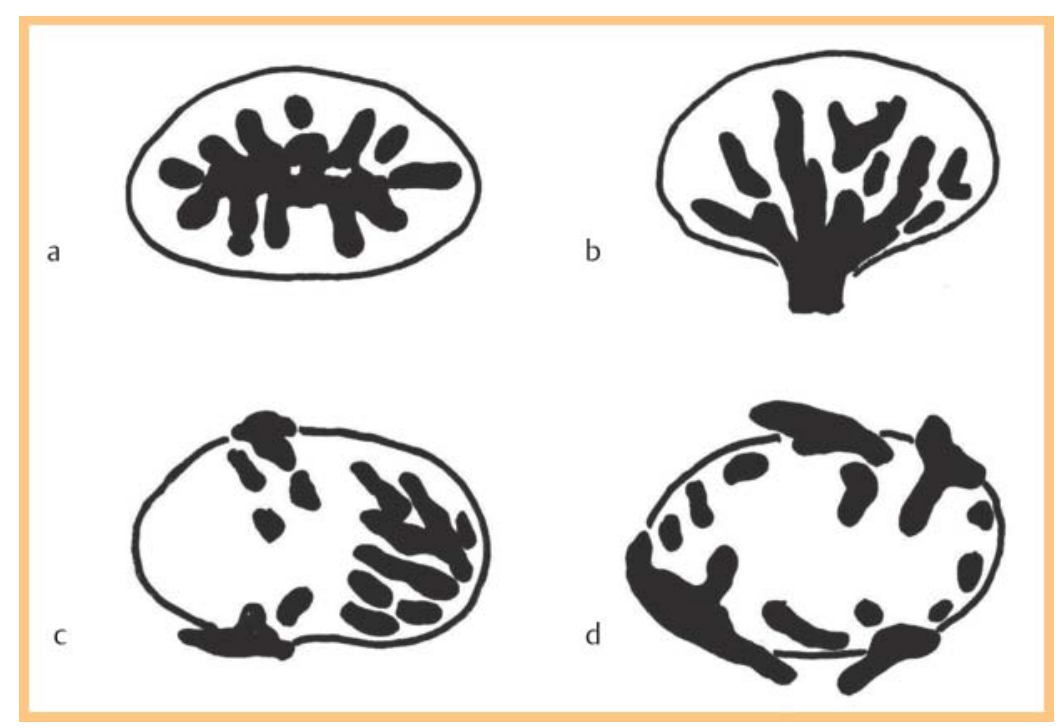

Fig. 1 Vascular patterns on color/power Doppler sonography. a, b are normal findings with regular vascular trees that emanate from the hilum outward toward the periphery. The capsular region is negative on color/power Doppler sonography. The differences between a, b are due to different views of the lymph node. c, $\mathbf{d}$ show vascular patterns suspicious for malignancy. Signficant transformation of the vascular tree with absence of the normal vascular hilum. c shows a hypervascularized and "avascular" area. $\mathbf{d}$ shows a peripherally intensified pattern with vessels with extracapsular extension and a spotted vascular pattern in some areas.

Abb. 1 Schema farb/powerdopplersonografischer Gefäßmuster. a, b sind Normalbefunde mit regulären Gefäßbäumen von hilär ausgehend in die Peripherie ausstrahlend. Die Kapselregion ist jeweils ausgespart. Die Unterschiede von a, b sind durch unterschiedliche Anschnitte des Lymphknotens bedingt. c, d zeigen malignomsuspekte Gefäßmuster. Deutliche Umwandlung des Gefäßbaums mit Fehlen des normalen Gefäßhilus. c weist ein hypervaskularisiertes und „avaskuläres“ Areal auf. d zeigt ein peripher betontes Muster mit kapselüberschreitenden Gefäßen und teilweise ein gesprenkeltes (spotted) Gefäßbild.

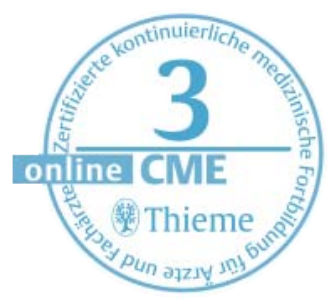

lymph nodes as a result of the distance of the lymph nodes from the surface of the skin, the quality of the ultrasound unit, and the unit settings $[5,13]$.

\section{Pulsed Doppler}

Pulsed Doppler is used to derive the blood flow spectrum of a vessel. Parameters such as the systolic and end-diastolic velocity, the resistance index (RI), and the pulsatility index (PI) can be determined. However, determination of these parameters is complicated and susceptible to artifacts, and the reliability of the criteria is controversial in the literature $[14,15]$. Therefore, they do not play a major role in the daily routine.

In general, blood vessels in malignant tumors have a higher RI and PI than normal blood vessels due to stenoses, vascular occlusions, and tumor pressure [13, $15-17]$. In contrast, AV shunts result in a very low RI, as described for different tumors $[16,17]$. Therefore, different flow patterns can often be measured in different vessels and vessel segments in a single tumor [16]. An increased RI ( $>0.8)$, in particular $>=1$, an increased PI $(>1.5)$, and RI differences in a single lymph node can be used as malignancy criteria and are considered to be relatively specific for lymph node metastases at a low sensitivity $[6,13,15,17]$.
An RI $<0.8$ and a PI $<1.5$ are typical for benign lymph nodes but also for malignant lymphomas and significant overlapping with the values for lymph node metastases is known $[15,17]$.

\section{Doppler sonography of peripheral lymph} nodes: Tips and technical pitfalls

The unit setting should be very sensitive in order to detect as many blood vessels as possible on color/power Doppler sonography. A low pulse repetition frequency (PRF 400-1000) and a low wall filter (WF 50-100) are selected so that slow blood flows can also be visualized $[5,10]$. The gain is increased to the point of significant color noise and is then slowly reduced until a usable signal-to-noise ratio is reached. This is the case when only a few noise pixels remain $[5,10]$.

The fact that a signal at a constant position can be reproduced as often as desired is important for differentiating between a color/power Doppler artifact and signal. In addition, pulsed Doppler, which does not show a proper venous or arterial flow spectrum in the case of an artifact, can help in cases of doubt.

The Doppler frequency must correspond to the required penetration depth. When relatively deep-seated lymph nodes (e.g. in the axilla) are examined, the Doppler frequency must be reduced (maximally) when using high-frequency probes to obtain signals at the necessary depth. In the case of deep-seated lymph nodes, a switch to a lower-frequency probe is often advantageous.

In the case of superficial structures, even light mechanical pressure with the probe suppresses vascular perfusion and thus reduces the detectability of vessels and changes parameters such as the resistance index (RI) and pulsatility index (PI) $[7,10,17]$. Pressure should therefore be minimized or ideally completely avoided during Doppler measurements [10]. This is achieved in that the ulnar portion of the examiner's hand rests on the patient's skin and the probe is deliberately lifted slightly.

The following points must be taken into consideration for correct derivation of the Doppler spectrum: The measurement window is placed in an area with the highest color saturation; the vessel course should have a favorable Doppler angle (as far as possible from the right angle to the scanning direction); only derivations with a clear signal and defined upper spectrum limit are used for analysis; the lowest possible probe pressure is to be ensured when determining and analyzing the diastolic flow since even normal pressure can significantly reduce or even stop diastolic flow [16].

\section{New sonographic techniques $\nabla$}

Contrast-enhanced ultrasound can provide realtime visualization of the smallest blood vessels as well as perfusion patterns that cannot be seen 
zur Umwandlung des Gefäßbaumes führt. Einschränkend ist auch, dass abhängig von der Distanz der Lymphknoten von der Hautoberfläche, der Qualität des Ultraschallgerätes und der Geräteeinstellung, sowohl in normalen als auch pathologischen Lymphknoten häufig gar keine Blutgefäße detektierbar sind [5, 13].

\section{Gepulster Doppler}

Der gepulste Doppler dient der Ableitung des Blutflussspektrums eines Gefäßes, wobei Parameter wie die systolische und enddiastolische Geschwindigkeit, der Widerstandsindex (RI) und der Pulsatilitätsindex (PI) bestimmt werden können. Die Bestimmung der Parameter ist aufwändig, artefaktanfällig und die Verlässlichkeit der Kriterien wird in der Literatur kontrovers beurteilt [14, 15], sodass diese in der täglichen Routine keine wesentliche Rolle spielen.

Grundsätzlich ist es so, dass Blutgefäße in malignen Tumoren einerseits durch Stenosen, Gefäßverschlüsse und dem Tumordruck höhere RI und PI aufweisen, als normale Blutgefäße [13, 15 - 17]. Andererseits führen AV-Shunts zu sehr niedrigen RI, wie dies für verschiedene Tumoren beschrieben ist $[16,17]$. In ein und demselben Tumor können in verschiedenen Gefäßen und Gefäßabschnitten daher oft unterschiedliche Flussmuster gemessen werden [16]. Ein erhöhter RI $(>0,8)$ insbesondere $>=1$, erhöhte PI $(>1,5)$ und RI-Unterschiede in ein und demselben Lymphknoten können als Malignitätskriterien herangezogen werden und gelten als relativ spezifisch für Lymphknotenmetastasen bei niedriger Sensitivität $[6,13,15,17]$.

Ein $\mathrm{RI}<0,8$ und $\mathrm{PI}<1,5$ sind typisch für benigne Lymphknoten, aber auch für maligne Lymphome und eine deutliche Überschneidung mit den Werten von Lymphknotenmetastasen sind bekannt $[15,17]$.

\section{Dopplersonografie der peripheren Lymphknoten: Tipps und Fallgruben}

Das Gerät sollte sehr sensitiv eingestellt werden, um möglichst viele Blutgefäße farb/powerdopplersonografisch zu detektieren. Dazu wählt man eine niedrige Pulsrepititionsfrequenz (PRF 400 1000) und einen niedrigen Wandfilter (WF 50 100) zur Erfassung auch langsamer Blutflüsse $[5,10]$. Dann erhöht man die Gain bis zum deutlichen Farbrauschen und dreht sie anschließend langsam wieder solange zurück, bis ein brauchbares Signal-Rausch-Verhältnis vorliegt. Dies ist dann gegeben, wenn nur noch wenige Rauschpixel auftreten $[5,10]$.

Zur Unterscheidung zwischen Farb/Powerdopplerartefakt und -signal dient, dass ein Signal an konstanter Stelle beliebig oft reproduzierbar ist. Zusätzlich kann im Zweifelsfall der gepulste Doppler helfen, der beim Artefakt kein regelrechtes venöses oder arterielles Flussspektrum zeigt. Die verwendete Dopplerfrequenz benötigt eine Abstimmung auf die erforderliche Eindringtiefe.
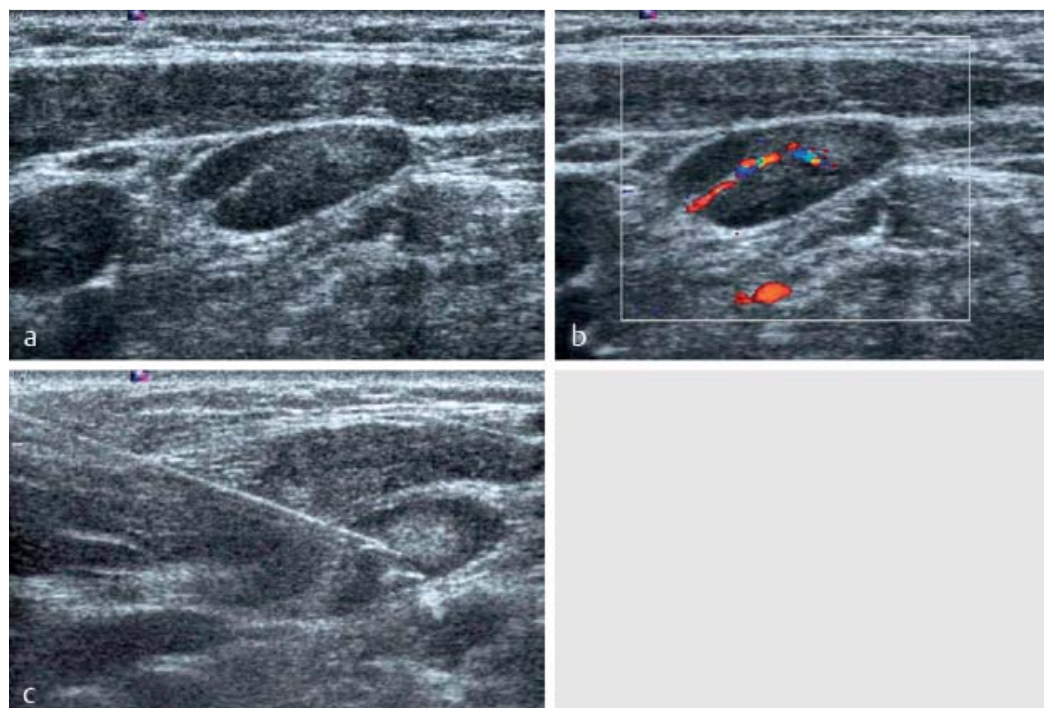

Fig. 2 Transverse sections of a hyperplastic lymph node (short-axis diameter $7 \mathrm{~mm}$ ) on the left in the middle cervical region in a patient with breast cancer. The lymph node was described on computed tomography as suspicious for metastasis. a B-mode image with uniform cortical structure and narrow hyperechoic hilum (preserved sonographic lymph node architecture). b Color Doppler sonographic image (7.3 MHz, 900 PRF, 50 WF) with proper hilar vascular pattern. c Ultrasound-guided core biopsy (18 G) for confirmation of the diagnosis.

Abb.2 Querschnitte eines hyperplastischen Lymphknotens (Kurzachsendurchmesser $7 \mathrm{~mm}$ ) links im mittleren Halsbereich bei einer Patientin mit Mammakarzinom. Der Lymphknoten wurde in der Computertomografie als metastasensuspekt beschrieben. a B-Bild mit gleichmäßiger Kortexstruktur und schmalem echoreichen Hilus (erhaltene sonografische Lymphknotenarchitektur). b farbdopplersonografisches Bild (7,3 MHz, 900 PRF, 50 WF) mit regelrechtem hilären Gefäßmuster. c Ultraschallgezielte Stanzbiopsie (18 G) zur Diagnosesicherung.
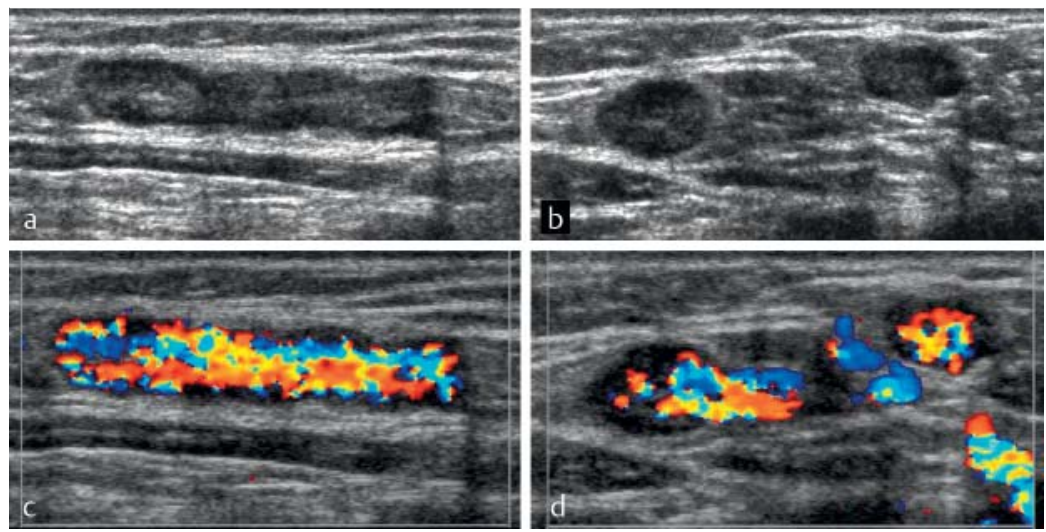

Fig. 3 Acute inflammatory lymph nodes of the groin in erysipelas of the lower leg. a Lymph nodes shown in longitudinal section and $\mathbf{b}$ transverse section with uniform widening of the cortex (cortical width $3.5 \mathrm{~mm}$ ) and still visualizable hilum (preserved sonographic lymph node architecture). c, d Significantly increased central vascularization with preserved vascular tree on color Doppler sonography (8.5 MHz, 700 PRF, 50 WF).

Abb.3 Akut entzündliche Lymphknoten der Leistenregion bei Erysipel des Unterschenkels. a Lymphknoten im Längsschnitt und b Querschnitt mit gleichmäßig verbreitertem Kortex (Kortexbreite 3,5 mm) und noch nachweisbarem Hilus (erhaltene sonografische Lymphknotenarchitektur). c, d In der Farbdopplersonografie (8,5 MHz, 700 PRF, 50 WF) ausgeprägt gesteigerte Vaskularisation von zentral bei erhaltenem Gefäßbaum.

Wenn relativ tiefliegende Lymphknoten (z. B.: in der Axilla) untersucht werden, muss die Dopplerfrequenz bei der Verwendung hochfrequenter Sonden (maximal) reduziert werden, um in der erforderlichen Tiefe Signale zu erhalten. Bei tieflie-

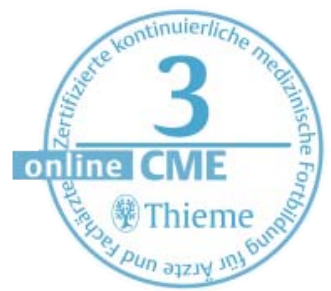



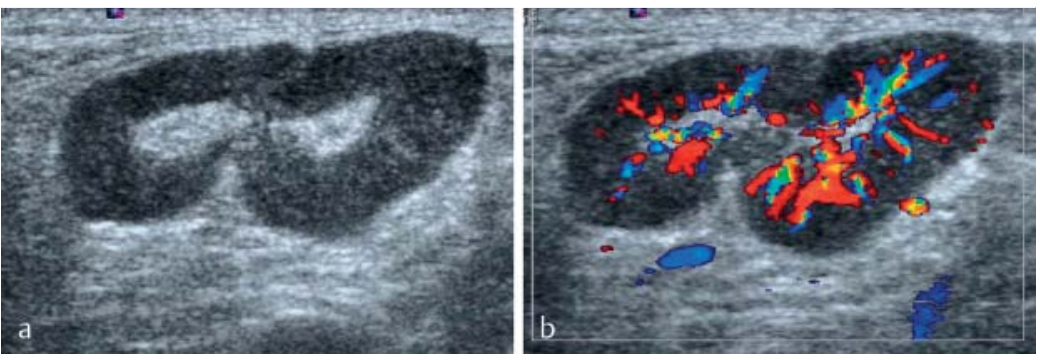

Fig. 4 Chronically inflamed lymph node of the groin in a patient with chronic ulcus cruris a on B-mode image and b color Doppler sonographic image. The cortex is uniformly widened (cortical width $5 \mathrm{~mm}$ ), the hilum is visible (preserved sonographic lymph node architecture). The vascularization is increased and the vascular tree is preserved on color Doppler sonography $(8.9 \mathrm{MHz}$, 900 PRF, 50 WF).

Abb.4 Chronisch-entzündlicher Lymphknoten der Leistenregion bei einem Patienten mit Ulcus cruris chronicum a im B-Bild und b farbdopplersonografischem Bild. Der Kortex ist gleichmäßig verbreitert (Kortexbreite $5 \mathrm{~mm}$ ), der Hilus nachweisbar (erhaltene sonografische Lymphknotenarchitektur). In der Farbdopplersonografie (8,9 MHz, 900 PRF, 50 WF) ist die Vaskularisation gesteigert, der Gefäßbaum erhalten.
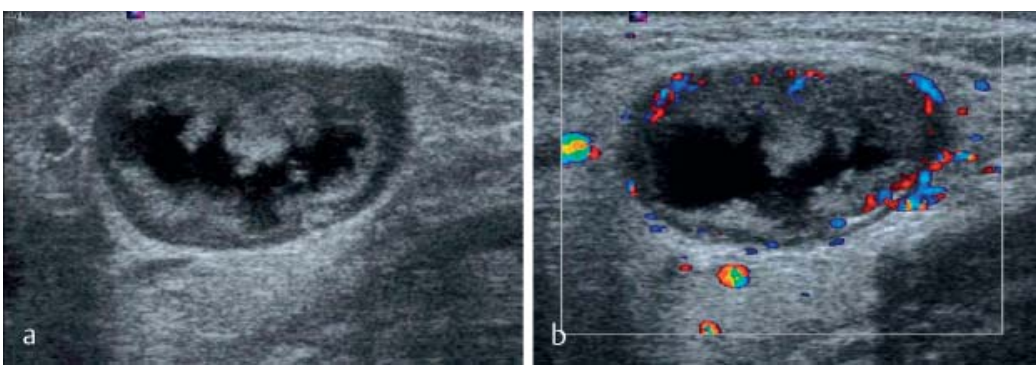

Fig. 5 Centrally necrotic lymph node metastasis in the submandibular region in squamous cell carcinoma of the floor of the mouth a on B-mode image and b color Doppler sonographic image. Destruction of normal sonographic lymph node architecture of the significantly enlarged lymph node (short-axis diameter $17 \mathrm{~mm}$ ) and extensive, largely anechoic, liquid, central necrosis. The color Doppler sonographic image (8.9 MHz, 900 PRF, 50 WF) shows only irregular peripheral vascularization at times with vessels with extracapsular extension.

Abb. 5 Zentral nekrotische Lymphknotenmetastase submandibulär bei Plattenepithelkarzinoms des Mundbodens a im B-Bild und b farbdopplersonografischem Bild. Aufhebung der normalen sonografischen Lymphknotenarchitektur des deutlich vergrößerten Lymphknotens (Kurzachsendurchmesser $17 \mathrm{~mm}$ ) und ausgedehnte, weitgehend echofreie, liquide, zentrale Nekrose. Im farbdopplersonografischen Bild (8,9 MHz, 900 PRF, 50 WF) nur irreguläre periphere Vaskularisation zum Teil mit kapselüberschreitenden Gefäßen.

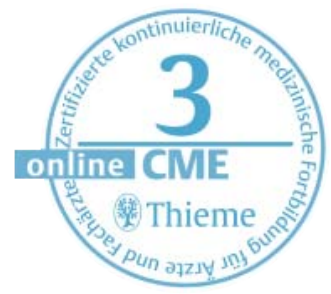

with conventional Doppler sonography. Various scientific studies have addressed the use of contrast-enhanced ultrasound in peripheral lymph nodes with the most promising results being in selected patient collectives (breast cancer, cutaneous malignant melanoma) $[18,19]$. Most of the studies include small case numbers and the applied vascularization criteria are not uniform, for example the more sensitive imaging of the classic color/power Doppler criteria or perfusion pattern [20]. Some authors specified hyperperfusion as a criterion for the perfusion patterns [18], while other authors specified inhomogeneities and hypoperfusion as signs [19]. The contrast medium behavior of lymph nodes in the case of malignant lymphomas and the different benign lymphadenopathies has only been minimally examined to date. However, the few results show that similarly to B-mode and color/ power Doppler sonography, contrast-enhanced ul- trasound seems to show significant overlapping between malignant lymphomas and inflammatory lymph nodes [20, 21]. Necrotic zones and liquefied areas in lymph nodes, as particularly known in the case of squamous cell carcinoma, bacterial abscessforming lymphadenitis, and tuberculosis, can be effectively visualized with contrast-enhanced ultrasound as circumscribed vascularization defects because ultrasound contrast media remain strictly intravascular (20, own observation). These zones cannot always be seen on B-mode and color/power Doppler sonography. When planning a diagnostic puncture, such as fluid aspiration in the case of colliquating lymphadenitis, or to avoid a necrotic zone during core biopsy, it can be advantageous to be able to detect necrotic zones and liquefied areas with high sensitivity (20, own observation). It should also be taken into consideration that the use of ultrasound contrast media is currently only possible "off label" $[20,21]$. Due to the insufficient data, contrast-enhanced ultrasound is not (yet) recommended for clinical use in peripheral lymph nodes in the current EFSUMB guidelines [20].

With the help of elastography, sonography can determine the hardness of soft tissues and can therefore help to differentiate normal liver from substantially harder fibrocirrhotic liver as an example of an established clinical application area. In general, this technique can also be used for peripheral lymph nodes. It has been shown in various studies that carcinoma metastases are usually harder than normal lymph nodes on elastography [22-25]. As in the case of contrast-enhanced ultrasound in peripheral lymph nodes, promising results have also been achieved for elastography in selected small patient collectives (ENT tumors, breast cancer, and cutaneous melanoma). However, definitive, sufficiently large studies regarding this topic are currently not available [23-25]. There is little data also in this case as to whether elastography can be helpful for malignant lymphomas and benign lymphadenopathies [22]. Various available elastography techniques and evaluation criteria additionally complicate applicability for patient care so that elastography is not recommended for routine use in peripheral lymph nodes in the current EFSUMB guidelines [22, 26]. This could change as evidenced by the use of endoscopic sonography in lymph nodes for which elastography was examined more extensively [26, 27].

\section{Sonographic findings of distinct entities} $\nabla$

Inflammatory reactive lymph nodes

Inflammation of different origins results in widening of the hypoechoic lymph node cortex. This occurs uniformly so that the sonographic lymph node architecture is preserved ( $\odot$ Fig. 3, 4) [28]. The widening of the cortex results in a minor to significant increase in the short-axis diameter 
genden Lymphknoten ist dabei der Wechsel auf eine niederfrequentere Sonde oft vorteilhaft.

Bei oberflächlichen Strukturen führt schon leichter mechanischer Druck mit dem Schallkopf zur Unterdrückung der Gefäßperfusion und damit zur Reduktion der Detektierbarkeit von Gefäßen und Änderung der Parameter wie Widerstandsindex (RI) und Pulsatilitätsindex (PI) [7, 10, 17]. Der Druck sollte deshalb während der Messungen mittels Doppler bewusst minimiert oder besser gänzlich vermieden werden [10]. Dies wird dadurch erreicht, dass der ulnare Teil der untersuchenden Hand auf der Patientenhaut aufliegt und die Hand den Schallkopf bewusst etwas anhebt.

Zur korrekten Ableitung des Dopplerspektrums sind folgende Punkte zu beachten: Das Messfenster wird in ein Areal mit möglichst satter Farbdarstellung gelegt; der Gefäßverlauf sollte einen günstigen Dopplerwinkel aufweisen (möglichst deutlich entfernt vom rechten Winkel zur Einschallrichtung); nur Ableitungen mit klarem Signal und scharfer Spektrumgrenze nach oben werden zur Analyse verwendet; bei Bestimmung und Analyse des diastolischen Strömungsanteiles ist besonders auf möglichst niedrigen Druck mit dem Schallkopf zu achten, denn schon durch normalen Druck kann der diastolische Anteil deutlich reduziert werden oder gänzlich verloren gehen [16].

\section{Neue sonografische Techniken}

$\nabla$

Die Kontrastmittelsonografie kann auch kleine und kleinste Blutgefäße, sowie Perfusionsmuster in Echtzeit darstellen, die mit der konventionellen Dopplersonografie nicht erkennbar sind. Mehrere wissenschaftliche Studien haben sich mittlerweile mit der Kontrastmittelsonografie an peripheren Lymphknoten beschäftigt, wobei ermutigende Ergebnisse vor allem an selektionierten Patientenkollektiven (Mammakarzinom, kutanes malignes Melanom) vorliegen [18, 19]. Großteils umfassen die Studien geringe Fallzahlen und die dabei angewandten Vaskularisationskriterien sind uneinheitlich, wie zum Beispiel die sensitivere Darstellung der klassischen Farb/Powerdopplerkriterien oder Perfusionsmuster [20]. Bei den Perfusionsmustern wird einerseits die Hyperperfusion als Kriterium angegeben [18], andere Autoren fanden Inhomogenitäten und die Hypoperfusion als Zeichen [19]. Das Kontrastmittelverhalten von Lymphknoten bei malignen Lymphomen und den unterschiedlichen benignen Lymphadenopathien wurde bislang wenig untersucht, wobei sich an den spärlichen Ergebnissen zeigt, dass ähnlich wie im B-Bild und der Farb/Powerdopplersonografie, kontrastmittelsonografisch eine deutliche Überschneidung zwischen malignen Lymphomen und entzündlichen Lymphknoten vorzuliegen scheint [20, 21]. Nekrosezonen und liquifizierte Areale in Lymphknoten, wie sie besonders für das Plattenepithelkarzinom, die bakterielle abszedierende Lymphadenitis und
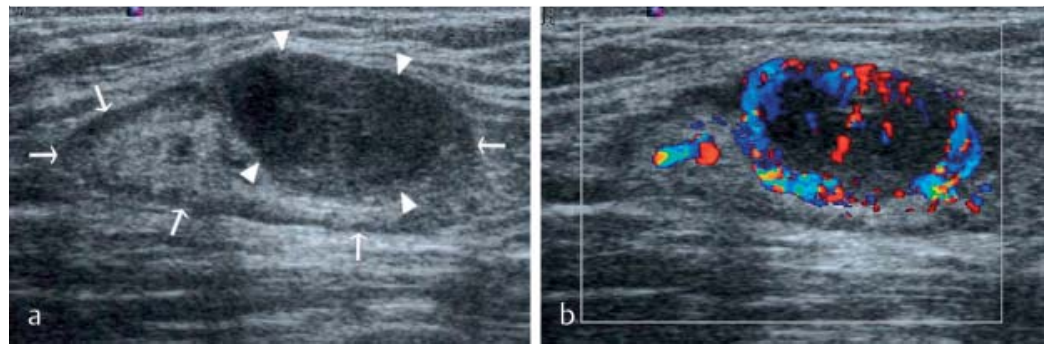

Fig. 6 Partially affected lymph node in the groin due to melanoma metastasis a on B-mode image and $\mathbf{b}$ color Doppler sonographic image. Part of the lymph node is visualized as normal (arrows) with a narrow hypoechoic cortex (cortical width up to $1.5 \mathrm{~mm}$ ) and a wide hyperechoic hilum. The metastasis corresponds to the nodular, hyperechoic cortical widening $(14 \times 8 \mathrm{~mm})$ (arrow tips). Color Doppler sonography ( $8.9 \mathrm{MHz}, 900 \mathrm{PRF}, 50 \mathrm{WF)}$ ) shows normal hilar vessels and pronounced, peripherally intensified tumor vascularization.

Abb. 6 Partiell befallener Lymphkonten der Leistenregion durch eine Melanommetastase a im B-Bild und b farbdopplersonografischem Bild. Ein Teil des Lymphknotens ist normal abgebildet (Pfeile) mit schmalem echoarmen Kortex (Kortexbreite bis 1,5 mm) und breitem echoreichen Hilus. Die Metastase entspricht der nodulären, echoarmen Kortexverbreiterung $(14 \times 8 \mathrm{~mm})$ (Pfeilspitzen). Die Farbdopplersonografie (8,9 MHz, 900 PRF, 50 WF) zeigt normale Hilusgefäße und eine ausgeprägte, peripher betonte Tumorvaskularisation.
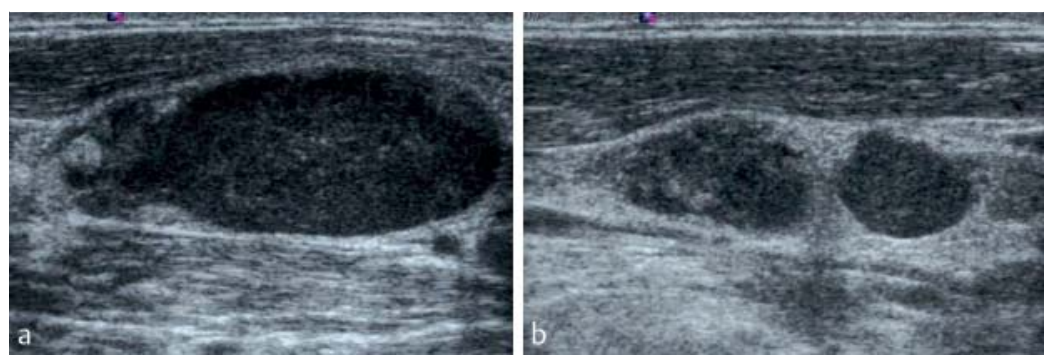

Fig. 7 Affected lymph nodes in the lower cervical region in Hodgkin's disease (short-axis diameter $12 \mathrm{~mm}$ in a, 8 and $7 \mathrm{~mm}$ in b). The normal sonographic lymph node architecture is destroyed, and the internal structure appears partially homogeneous and partially significantly inhomogeneous. The Solbiati index in a is substantially greater than 2 .

Abb. 7 Befallene Lymphknoten im unteren zervikalen Bereich bei Morbus Hodgkin (Kurzachsendurchmesser $12 \mathrm{~mm}$ in a, 8 und $7 \mathrm{~mm}$ in b. Die normale sonografische Lymphknotenarchitektur ist zerstört, wobei die Binnenstruktur zum Teil homogen und zum Teil deutlich inhomogen erscheint. Der Solbiati-Index in a ist deutlich größer als 2.

die Tuberkulose bekannt sind, können mit der Kontrastmittelsonografie als umschriebene Vaskularisationsdefekte gut dargestellt werden, weil Ultraschallkontrastmittel streng intravaskulär verbleiben ([20], eigene Beobachtung). Diese Zonen sind mittels B-Bild und Farb/Powerdoppler nicht immer erkennbar. Bei der Planung einer diagnostischen Punktion, wie einer Flüssigkeitsaspiration bei einschmelzender Lymphadenitis oder zum Meiden einer wenig aussagekräftigen Nekrosezone bei einer Stanzbiopsie, kann das sensitive Erkennen der Nekrosezonen und liquifizierten Areale von Vorteil sein ([20], eigene Beobachtung). Zu bedenken ist auch, dass die Anwendung von Ultraschallkontrastmitteln derzeit nur "off-label“ möglich ist $[20,21]$. Aufgrund der unzureichenden Datenlage wird die Kontrastmittelsonografie an peripheren Lymphknoten in den aktuellen EFSUMB Guidelines für den klinischen Einsatz (noch) nicht empfohlen [20].

Mithilfe der Elastografie kann die Sonografie die Härte von Weichteilgeweben erfassen und so als 

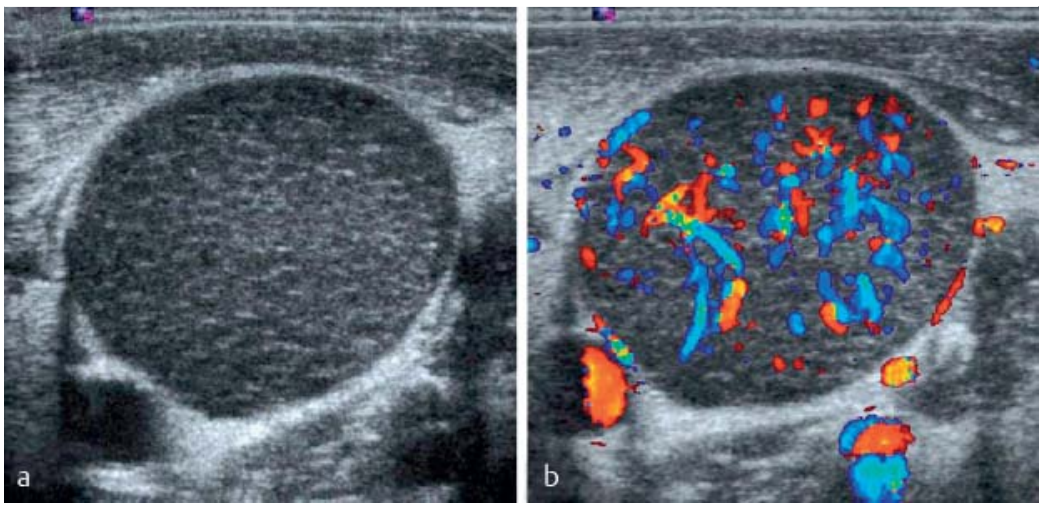

Fig. 8 Greatly enlarged, rounded, affected lymph node ( $22 \mathrm{~mm}$ short-axis diameter) in the lower cervical region in follicular lymphoma a on B-mode image and b color Doppler sonographic image. a Homogeneous speckled internal structure. b Significantly increased, relatively uniform vascularization (7.3 MHz, $900 \mathrm{PRF}, 50 \mathrm{WF})$.

Abb. 8 Stark vergrößerter, rundlicher, befallener Lymphknoten ( $22 \mathrm{~mm}$ Kurzachsendurchmesser) im unteren zervikalen Bereich bei follikulärem Lymphom a im B-Bild und b farbdopplersonografischem Bild. a Homogen getüpfelte Binnenstruktur. b Deutlich gesteigerte, relativ gleichmäBige Vaskularisation (7,3 MHz, 900 PRF, $50 \mathrm{WF})$.

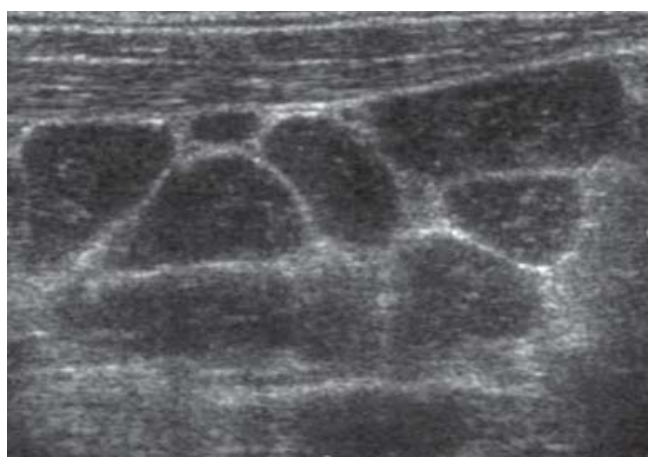

Fig. 9 Image of the "chain-like" lymph node configuration in the lower cervical region in lymph node involvement in chronic lymphocytic leukemia (CLL). The enlarged lymph nodes (short-axis diameter of up to $13 \mathrm{~mm}$ ) are homogeneously hypoechoic. Only narrow "linking segments" of surrounding fat and connective tissue are between the individual lymph nodes.

Abb. 9 Bild der „kettenartigen“ Lymphknotenanordnung im unteren zervikalen Bereich bei Lymphknotenbefall im Rahmen einer chronischen lymphatischen Leukämie (CLL). Die vergrößerten Lymphknoten (bis $13 \mathrm{~mm}$ im Kurzachsendurchmesser) sind homogen echoarm. Zwischen den einzelnen Lymphknoten sind nur schmale „Fugen“ von umgebendem Fett- und Bindegewebe.

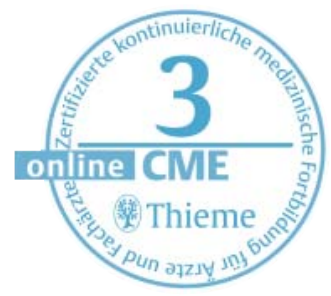

and uniform narrowing of the hyperechoic hilum. Color/power Doppler sonography shows minor to significant enhancement of the normal vascular tree ( $\bullet$ Fig. 3, 4) $[6,9,13]$. Deviations from this practically only occur in the case of colliquating lymph nodes.

One or more lymph nodes in the lymphatic drainage area of the portal of entry of the pathogen are affected by inflammation. Lymphatic drainage areas that are frequently affected include the inguinal region of the leg, the axilla of the arm, the submandibular region (region Ib), the upper cervical region (region II) on both sides of the nasopharynx, and nuchal lymph nodes in the rear section of the haired scalp.

Dermatopathic lymphadenopathy refers to reactively enlarged lymph nodes due to a disruption of the skin integrity in the case of various diseases such as psoriasis vulgaris and erythroderma.
These are usually inguinal and axillary in the lymphatic drainage area of the affected skin areas. The sonographic appearance corresponds to that of inflammatory reactive lymph nodes [29]. In the case of peripheral lymphadenopathy, the possibility of a skin disease and a port of entry should therefore always be examined as the cause [29]. Inflammatory lymph nodes are typically painful with the pain being greatest in the case of acute non-specific lymphadenitis. It must be taken into consideration that some inflammatory lymphadenopathies, particularly chronic ones, are not necessarily painful, while neoplastic processes can cause localized symptoms if they are rapidly growing.

\section{Malignant lymphomas}

Malignant lymphomas comprise a large heterogeneous group of neoplasias. The imaging appearance can differ accordingly. Most malignant lymphomas often affect the peripheral lymph node stations, while such a finding is a rarity in the case of plasmacytoma. Affected lymph nodes are frequently enlarged and have a particularly hypoechoic structure $[21,30]$. The normal sonographic lymph node architecture can be preserved (often in the case of CLL) or can be altered ( $\bullet$ Fig. 7) [21]. In the case of a preserved sonographic lymph node architecture, the appearance is similar to that of inflammatory reactive lymph nodes [21]. The following typical but not absolutely specific morphological signs are known: Hypoechoic, homogeneous internal structure; uniform internal structure with hypoechoic speckling that is observed primarily in CLL and follicular lymphoma ( $\bullet$ Fig. 8) [31, 32]; image of enlarged lymph nodes strung together like a chain with narrow hyperechoic linking segments that correspond to the surrounding fat/connective tissue ( $\boldsymbol{\bullet}$ Fig. 9 ) [21]; small vessel sign with the small vessels being elongated arteries visible on B-mode ultrasound within the pathological lymph nodes [30].

In contrast to the often chain-like configuration of the lymph nodes in pronounced cases of lymphoma, lymph node metastases of carcinomas tend to be more spread out. Bulk refers to a lymphoma mass with a maximum diameter of at least $10 \mathrm{~cm}$ that rarely occurs at the peripheral lymph node stations and when it occurs then usually with extensive extranodal extension. In particular, highly malignant lymphomas tend toward extracapsular extension and extensive hypoechoic infiltrates.

Despite the often very hypoechoic, seemingly "pseudocystic" character with dorsal acoustic enhancement, the lymph nodes have a solid structure. Cystic changes, necroses, or calcifications are rare [14, 33]. Modern high-resolution probes and a high gain setting make it possible to determine that the pseudocystic character is actually solid [32]. In cases of doubt, color/power Doppler can be useful for proving the solid character. 
Beispiel für ein etabliertes klinisches Einsatzgebiet die normale Leber von der wesentlich härteren fibrozirrhotischen Leber differenzieren helfen. An peripheren Lymphknoten ist diese Technik grundsätzlich auch anwendbar, wobei sich in mehreren Studien zeigte, dass Karzinommetastasen meist elastografisch härter zur Darstellung kommen als normale Lymphknoten [22 - 25). Ähnlich wie für die Kontrastmittelsonografie an peripheren Lymphknoten gilt auch für die Elastografie, dass ermutigende Ergebnisse an selektionierten kleinen Patientenkollektiven (HNO-Tumoren, Mammakarzinom und kutanes Melanom) vorliegen, aber aussagekräftige, ausreichend groß angelegte Studien zu dem Thema fehlen [23 - 25]. Auch hier gibt es wenige Daten, ob die Elastografie bei malignen Lymphomen und bei den einzelnen benignen Lymphadenopathien hilfreich sein kann [22]. Verschiedene verfügbare elastografische Techniken und Beurteilungskriterien erschweren zusätzlich die Anwendbarkeit im Patientenbetrieb, sodass derzeit die Elastografie zum Routineeinsatz an peripheren Lymphknoten in den aktuellen EFSUMB Guidelines nicht empfohlen wird [22, 26]. Dies könnte sich durchaus ändern, wie die endoskopische Sonografie an Lymphknoten zeigt, für die die Elastografie ausgiebiger untersucht wurde $[26,27]$.

\section{Sonografische Befunde bestimmter Entitäten \\ $\nabla$}

\section{Entzündlich reaktive Lymphknoten}

Im Rahmen von Entzündungen unterschiedlicher Genese kommt es zu einer Verbreiterung des echoarmen Lymphknotenkortex. Diese erfolgt gleichmäßig, sodass die sonografische Lymphknotenarchitektur erhalten bleibt ( $\bullet$ Abb.3, 4) [28]. Die Kortexverbreiterung führt zu einer geringen bis deutlichen Zunahme des Kurzachsendurchmessers und gleichmäßigen Einengung des echoreichen Hilus. Farb/Powerdopplersonografisch ist eine gering bis deutliche Akzentuierung des normalen Gefäßbaumes nachzuweisen ( $\bullet$ Abb. 3, 4) $[6,9,13]$. Abweichungen davon finden sich praktisch nur bei einschmelzenden Lymphknoten.

Von der Entzündung betroffen sind ein oder mehrere Lymphknoten im Lymphabflussgebiet der Erregereintrittspforte. Häufig betroffene Lymphabflussgebiete sind typischerweise die Inguinalregion für das Bein, die Axilla für den Arm, die Submandibularregion (Regio $\mathrm{Ib})$ und obere Zervikalregion (Regio II) beidseits für den Nasenrachenraum sowie nuchale Lymphknoten für den hinteren Abschnitt der behaarten Kopfhaut.

Als dermopathische Lymphadenopathie bezeichnet man reaktiv vergrößerte Lymphknoten im Rahmen der Störung der Hautintegrität bei verschiedenen Erkrankungen wie Psoriasis vulgaris und Erythrodermie. Diese liegen meist inguinal
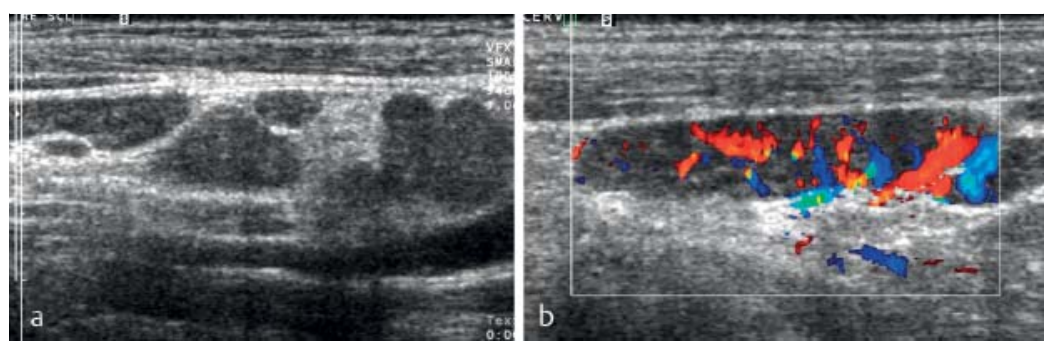

Fig. 10 a Supraclavicular lymph node involvement in sarcoidosis. The lymph nodes are only minimally enlarged (short-axis diameter of up to $9 \mathrm{~mm}$ ) and have a homogeneous hypoechoic structure. A hyperechoic hilum is not visualizable. b The color Doppler sonographic image (8.5 MHz, 700 PRF, 50 WF) shows increased vascularization with a largely preserved vascular tree.

Abb.10 a Lymphknotenbefall bei Sarkoidose supraklavikulär. Die Lymphknoten sind nur geringgradig vergrößert (bis $9 \mathrm{~mm}$ im Kurzachsendurchmesser) und homogen echoarm strukturiert. Ein echoreicher Hilus ist nicht nachweisbar. b Das farbdopplersonografische Bild $(8,5 \mathrm{MHz}$, 700 PRF, 50 WF) zeigt eine gesteigerte Vaskularisation bei weitgehend erhaltenem Gefäßbaum.

und axillär im Lymphabflussgebiet der großflächig betroffenen Hautareale. Das sonografische Erscheinungsbild entspricht dem von entzündlich reaktiven Lymphknoten [29]. Bei peripherer Lymphadenopathie sollte daher immer auch die Möglichkeit einer Hauterkrankung und einer Eintrittspforte als Ursache geprüft werden [29].

Meist sind entzündliche Lymphknoten schmerzhaft, wobei dies bei der akuten unspezifischen Lymphadenitis am ausgeprägtesten ist. $\mathrm{Zu}$ beachten ist, dass manche entzündliche Lymphadenopathien, insbesondere die chronischen, nicht schmerzhaft sein können und umgekehrt neoplastische Prozesse, insbesondere rasch wachsende, auch lokale Beschwerden verursachen können.

\section{Maligne Lymphome}

Maligne Lymphome sind eine große, heterogene Gruppe von Neoplasien. Dementsprechend unterschiedlich sind die Erscheinungsmuster in der Bildgebung. Die Mehrzahl führt oft zu einem Befall von peripheren Lymphknotenstationen, dagegen ist ein solcher Befund beim Plasmozytom eine Rarität. Häufig sind betroffene Lymphknoten vergrößert und sehr echoarm strukturiert [21,30]. Die normale sonografische Lymphknotenarchitektur kann erhalten (oft bei der CLL) oder verändert sein ( $\bullet$ Abb.7) [21]. Bei erhaltener sonografischer Lymphknotenarchitektur ähnelt das Erscheinungsbild dem entzündlich reaktiver Lymphknoten [21]. Als typisch, aber nicht absolut spezifisch, sind folgende morphologische Zeichen bekannt: die echoarme homogene Binnenstruktur; die gleichmäßige, echoarm-getüpfelte Binnenstruktur, die vor allem bei der CLL und dem follikulären Lymphom zu beobachten ist ( $\boldsymbol{A} \mathbf{A b b} . \mathbf{8})$ [31, 32]; das Bild der kettenartig aneinandergereihten, vergrößerten Lymphknoten mit schmalen echoreichen Fugen dazwischen, die umliegendem Fett/Bindegewebe entsprechen ( $\bullet$ Abb.9) [21]; das Zeichen der kleinen Gefäße (small vessel sign), die B-Bild sonografisch erkennbare, gestreckt verlaufenden Arte- 
Color/power Doppler sonography typically shows increased vascularization [13]. Vascular trees within the lymph nodes are often preserved but can also appear minimally to significantly altered ( $\bullet$ Fig. 8) Doppler spectral analysis does not allow the important differentiation between malignant lymphoma and inflammatory lymphadenopathy [13]. In general, imaging cannot be used to differentiate between individual subtypes of lymphoma.

Sonography is also established in the follow-up and aftercare of malignant lymphomas. In the case of complete remission after treatment, the often enlarged lymph nodes return to normal values. In the case of very extensive findings and bulks, a small inactive residuum that is enlarged beyond normal values can remain. The cornerstone of sonographic follow-up is the size of a finding. Comparability with previous studies requires exact measurement and documentation. In the case of multiple lymph nodes, the shortaxis diameter of the largest lymph node per region should be specified. Sonography and CT are typically used alternately in follow-up and aftercare to be able to take advantage of the lack of radiation of sonography and the ability to acquire the entire torso with CT.

\section{Lymph node metastases of solid tumors}

Lymphogenous metastasis is initially limited to the lymphatic drainage area of the primary tumor. The growth of metastases within lymph nodes is usually circumscribed and nodular and therefore typically significantly changes the sonographic lymph node architecture. Typical signs of this are eccentric widening of the cortex and an inhomogeneous internal structure ( $\bullet$ Fig. 5,6 ). This is often hypoechoic, but can rarely also be hyperechoic. Necrotic zones with varying degrees of echogenicity often occur [32, 34] with the greatest frequency being in the case of squamous cell carcinoma ( $\mathbf{F i g}$. 5). Color/power Doppler sonography typically shows significant changes to the normal vascular tree ( $\bullet$ Fig. 5,6 ) $[6,9]$. However, anaplastic carcinomas can rarely have a uniform appearance and perfusion pattern similar to that of malignant lymphomas or reactive lymph nodes ( Fig. 13). Lymphatic metastasis must reach a certain extent and size before being able to be detected. Micrometastases, metastases up to approximately $3 \mathrm{~mm}$ in size, and extracapsular microinvasions generally cannot be visualized with any imaging method. These are primarily described for squamous cell carcinomas in the ENT region and in the axillary region in breast cancer at a frequency of up to $20 \%$ [ 35 - 37].

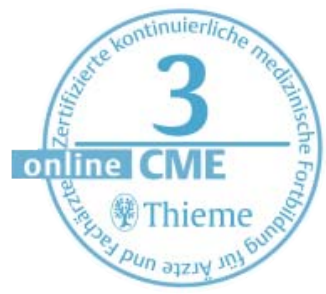

ve collaboration with the pathologist and special cytological expertise [19, 39].

Sonography is also important for the aftercare of peripheral lymph node stations in the lymphatic drainage area of malignant solid tumors, such as in the case of cutaneous melanomas, squamous cell carcinomas of the skin, and ENT tumors. This is initially usually performed in 3-month intervals.

\section{Sarcoidosis}

The organs most frequently affected in sarcoidosis are the lungs and lymph nodes with approximately $90 \%$ in each case. The hilar and mediastinal lymph nodes are the most affected lymph nodes. Peripheral lymph nodes, particularly the lower cervical, clavicular, and axillary lymph nodes, are also involved in one-third of patients. Isolated involvement of the peripheral stations without thoracic involvement is rare [40]. Occasionally the palpation finding of peripheral lymphadenopathy is the first manifestation because thoracic involvement often is not symptomatic. If peripheral lymph nodes are affected, these are usually only minimally to moderately enlarged and have a homogeneous structure on sonography ( $\bullet$ Fig. 10) [41]. Vascularization can appear normal or increased and the vascular tree can be normal or altered on color/power Doppler sonography ( $\bullet$ Fig. 10). The sonographic appearance is nonspecific and resembles that of malignant lymphomas and reactive lymph nodes more than that of solid tumors $[8,41]$. In the case of unclear peripheral lymphadenopathy, additional chest X-ray and/or CT of the torso in sarcoidosis will often guide the tentative diagnosis in the correct direction based on the typical pattern of involvement (asymptomatic bihilar lymphadenopathy with or without symmetrical pulmonary involvement). Sarcoidosis is diagnostically confirmed clinically, via lab tests, radiologically, and via biopsy, but the definitive differentiation from malignant lymphoma can only be performed histologically [8]. Peripheral lymphadenopathy in sarcoidosis is commonly used for diagnosis confirmation via excisional biopsy or ultrasound-guided core biopsy [40].

\section{Tuberculosis}

The hilar and mediastinal lymph nodes are usually affected in the case of tuberculosis of the lung which is the most frequently affected organ with approximately $80 \%$. Involvement of the peripheral lymph node stations is significantly less common with the neck, clavicular region, and the axilla being primarily affected. Lymph node tuberculosis tends to result in the formation of necroses, liquid areas, calcifications, extracapsular extension, and fistula formation [42]. The sonographic lymph node architecture and the color/power Doppler sonographic image often appear accordingly significantly changed ( $\bullet$ Fig. 11) $[6,32,43]$. Calcifications and fistulas can be considered relatively tuberculo- 
rien innerhalb der pathologischen Lymphknoten sind [30].

Im Gegensatz zur oft kettenartigen Anordnung der Lymphknoten bei ausgeprägtem Lymphombefall sind Lymphknotenmetastasen von Karzinomen hingegen eher einzeln stehend mit mehr Abstand dazwischen. Als Bulk wird eine zusammenhängende Lymphommasse von mindestens $10 \mathrm{~cm}$ im größten Durchmesser bezeichnet, die an den peripheren Lymphknotenstationen selten entsteht und wenn, dann meist durch eine ausgedehnte extranodale Ausbreitung. Besonders hochmaligne Lymphome neigen zur Kapselüberschreitung und ausgedehnten flächigen echoarmen Infiltraten.

Trotz des häufig sehr echoarmen, scheinbar „pseudozystischen" Charakters mit dorsaler Schallverstärkung sind die Lymphknoten zur Gänze solide gebaut. Zystische Veränderungen, Nekrosen oder Verkalkungen sind selten [14, 33]. Mit modernen hochauflösenden Schallköpfen und einer entsprechend hoch gewählten Gain ist der pseudozystische Charakter als solide zu erkennen [32]. In Zweifelsfällen kann der Farb/Powerdoppler hilfreich sein, den soliden Charakter zu beweisen.

Farb/Powerdopplersonografisch erscheint die Vaskularisation meist gesteigert [13]. Gefäßbäume innerhalb der Lymphknoten sind häufig erhalten, können aber auch gering bis deutlich verändert erscheinen ( $\bullet$ Abb. 8). Die Doppler-Spektralanalyse ermöglicht nicht die wichtige Differenzierung malignes Lymphom versus entzündliche Lymphadenopathie [13]. Die Bildgebung ermöglicht generell auch keine Differenzierung der einzelnen Lymphomsubtypen.

Die Sonografie ist auch etabliert in der Verlaufskontrolle und Nachsorge von malignen Lymphomen. Bei Komplettremission nach Therapie bilden sich die ursprünglich oft ausgeprägt vergrößerten Lymphknoten auf Normalwerte zurück. Bei sehr ausgedehnten Befunden und Bulks kann ein kleines, über die Norm vergrößertes inaktives Residuum zurückbleiben. Der Eckpfeiler der sonografischen Verlaufskontrolle ist die Größe eines Befundes. Die Vergleichbarkeit mit den Voruntersuchungen setzt jeweils eine exakte Vermessung und Dokumentation voraus, wobei im Falle von multiplen Lymphknoten der Kurzachsendurchmesser des größten Lymphknotens pro Region angegeben werden sollte. Sonografie und CT werden in der Verlaufskontrolle und Nachsorge meist alternierend eingesetzt, um einerseits die fehlende Strahlenbelastung der Sonografie und andererseits die Möglichkeit der Gesamterfassung des Körperstammes bei der CT als Vorteile nutzen zu können.

\section{Lymphknotenmetastasen solider Tumoren}

Die lymphogene Metastasierung ist zunächst auf das Lymphabflussgebiet des Primärtumors beschränkt. Das Wachstum von Metastasen in Lymphknoten erfolgt häufig umschrieben-knotig und verändert daher meist stark die sonografische Lymphknotenarchitektur. Typische Zeichen sind die exzentrische Kortexverbreiterung und die inhomogene Binnenstruktur ( $\bullet$ Abb.5, 6). Diese ist häufig echoarm, seltener kann sie auch echoreich sein. Nicht selten kommen Nekrosezonen unterschiedlicher Echogenität vor [32, 34], wobei diese besonders häufig beim Plattenepithelkarzinom sind (O Abb.5). Farb/Powerdopplersonografisch ist der normale Gefäßbaum meist deutlich verändert ( $\bullet$ Abb. 5, 6) $[6,9]$. Anaplastische Karzinome können jedoch selten ein ähnlich gleichmäßiges Erscheinungsbild und Durchblutungsmuster wie maligne Lymphome oder reaktive Lymphknoten aufweisen ( $\bullet$ Abb. 13). Der metastatische Befall eines Lymphknotens muss eine Ausdehnung und Größe erreichen, um detektiert werden zu können. Mikrometastasen, Metastasen bis etwa $3 \mathrm{~mm}$ Größe und eine extrakapsuläre Mikroinvasion sind generell mit keiner bildgebenden Methode nachzuweisen, wobei diese vor allem für Plattenepithelkarzinome im HNO-Bereich und axillär bei Mammakarzinom in einer Häufigkeit bis $20 \%$ beschrieben sind [ 35 - 37]. Da Lymphknotenmetastasen häufig mit reaktiv veränderten Lymphknoten vergesellschaftet sind und sich die Erscheinungsbilder überlappen, wird die Sonografie der Kopf/Halslymphknoten bei HNO-Tumoren häufig durch die sonografisch gezielte Feinnadelaspirationszytologie ergänzt $[19,38]$. Diese setzt eine intensive Zusammenarbeit mit dem Pathologen und eine spezielle zytologische Expertise voraus [19, 39].

Die Sonografie hat auch einen wichtigen Stellenwert in der Nachsorge von peripheren Lymphknotenstationen im Lymphabflussgebiet von malignen soliden Tumoren wie beispielsweise beim kutanen Melanom, bei Plattenepithelkarzinomen der Haut und HNO-Tumoren. Diese erfolgt meist zunächst in 3-Monatsintervallen.

\section{Sarkoidose}

Die bei der Sarkoidose am häufigsten befallenen Organe sind Lunge und Lymphknoten mit jeweils etwa $90 \%$. Die hilären und mediastinalen Lymphknoten sind dabei die am meisten betroffenen Gruppen. In einem Drittel der Patienten sind auch die peripheren Lymphknoten, vor allem die unteren zervikalen, klavikulären und axillären, involviert, wobei ein isolierter Befall der peripheren Stationen ohne thorakalen Befall selten ist [40]. Gelegentlich ist der Tastbefund einer peripheren Lymphadenopathie die klinische Erstmanifestation, weil der thorakale Befall häufig keine Beschwerden verursacht. Bei Befall der peripheren Lymphknoten sind diese meist nur gering- bis mäßiggradig vergrößert und erscheinen sonografisch homogen strukturiert ( $\bullet$ Abb. 10) [41]. Farb/Powerdopplersonografisch kann die Vaskularisation normal oder gesteigert und der Gefäßbaum unauffällig bis verändert sein ( $\bullet \mathbf{A b b}$. 10). Das sonografische Erscheinungsbild ist unspezifisch und ähnelt

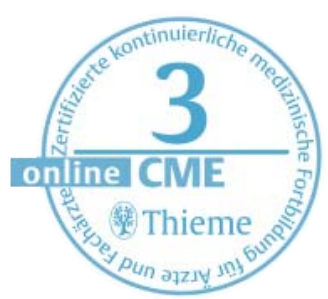




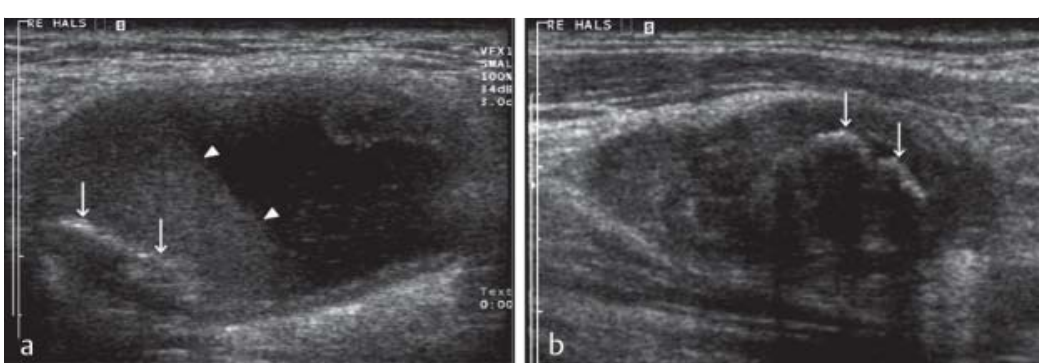

Fig. 11 Lymph node involvement in the neck due to chronic tuberculosis. a, b show two different lymph nodes in the middle and lower cervical region. The sonographic lymph node architecture of the significantly enlarged lymph nodes (short-axis diameter of $21 \mathrm{~mm}$ in a and $13 \mathrm{~mm}$ in b is no longer present. Both lymph nodes show a hyperechoic plaque-like calcification (arrows). a additionally shows extensive liquid necrosis with sediment level (arrow tips).

Abb. 11 Lymphknotenbefall am Hals durch chronische Tuberkulose. a und b zeigen zwei unterschiedliche Lymphknoten im mittleren und unteren Halsbereich. Die sonografische Lymphknotenarchitektur der deutlich vergrößerten Lymphknoten (Kurzachsendurchmesser von $21 \mathrm{~mm}$ in a und $13 \mathrm{~mm}$ in b) ist aufgehoben. Beide Lymphknoten zeigen eine echoreiche schollige Verkalkung (Pfeile). a zeigt zusätzlich eine ausgedehnte flüssige Nekrose mit Sedimentspiegel (Pfeilspitzen).

sis-specific ( $\bullet$ Fig. 11) $[35,42]$. In contrast to tuberculosis, lymph node calcifications in the case of inflammation of another origin and malignant diseases are very rare and can sometimes be seen after chemotherapy/radiation therapy [14, 32]. Exceptions include papillary and medullary thyroid carcinoma in which multiple dot-like calcifications often occur in the affected lymph nodes $[32,35]$. In the case of peripheral lymphadenopathy, the obligatory thorough examination including chest $\mathrm{X}$-ray and CT of the torso often provides diagnostic direction particularly on the basis of the typical pulmonary involvement of tuberculosis.

\section{Castleman disease}

Castleman disease is a rare lymphadenopathy of unknown origin that usually affects abdominal, mediastinal, or peripheral lymph nodes. There are two types: The more common localized type (approximately $90 \%$ of cases, usually histologically hyaline vascular) in which only one lymph node is affected, and the rarer multicentric type (approximately $10 \%$ of cases, usually histologically plasma cell-rich) in which more lymph nodes are affected. The localized type, which is usually asymptomatic, has a significantly better prognosis than the multicentric type, which is always symptomatic.

The lymph node(s) is/are moderately to significantly enlarged and typically appear to have a homogeneous structure on sonography [44]. Color/ power Doppler sonography often shows increased vascularization and the appearance of the vascular tree ranges from normal to altered. The sonographic appearance is non-specific and often resembles that of malignant lymphomas and reactive lymph nodes ( 0 Fig. 12) [44]. Diagnosis is made histopathologically via excisional or core biopsy. The treatment of choice in the localized type is complete surgical removal of the affected lymph node, which acts as a cure in approximately $90 \%$ of cases.

\section{Examples of rare entities}

Enlarged peripheral lymph nodes are common in cat-scratch disease, toxoplasmosis, Rosai-Dorfman disease, Kimura disease, and Kikuchi disease. In cat-scratch disease, a usually self-limiting infection caused by the bacterium bartonella henselae, which enters the skin as the result of a cat scratch or bite, the lymph nodes of the lymphatic drainage area of the port of entry (usually the axilla, neck, or crook of the arm) are affected [45]. Rosai-Dorfman disease is also usually a benign process of unknown origin involving significant swelling of the lymph nodes in the neck primarily in young patients [47]. Kimura disease and Kikuchi disease in Southeast Asia are also usually selflimiting diseases of unknown origin that are accompanied by lymphadenopathy in the neck [46, 47]. The affected lymph nodes of the specified entities are generally minimally to moderately enlarged. The sonographic lymph node architecture and the vascularization pattern are often preserved but can be altered in rare cases. The most important differential diagnoses are common inflammation and malignant lymphoma [45-47]. The sonographic appearance usually does not allow definitive differentiation. Therefore, the diagnoses must be made clinically, via lab tests, or via biopsy.

\section{Virchow's lymph node}

Involvement of the left supraclavicular Virchow's lymph node in the venous angle is an interesting particularity. A non-painful palpation finding in this region is occasionally the first clinical manifestation of a malignant disease. Metastasis occurs via the thoracic duct and is occasionally observed in pancreatic carcinoma, gastric carcinoma, or in general in wide-spread malignancies of the abdominal cavity and the retroperitoneum ( $\bullet$ Fig. 6 ). It is important for the examiner to be familiar with this special pathway of spread and this growth pattern and for a supplementary targeted examination of the abdominal cavity and the retroperitoneum to be subsequently performed as necessary. Additional CT of the torso provides a better overview of the morphological changes in regions that are difficult or impossible to access with sonography such as the thoracic cavity and retroperitoneum.

\section{Course of action based on the sonographic finding \\ $\nabla$}

In the case of a normal sonographic finding under consideration of the B-mode criteria described in Part 1 and the color/power Doppler sonography criteria, no further diagnostic procedures are necessary if sonography was performed for example due to an unclear palpation finding, if an unclear sonographic lymph node finding was previously acquired by an inexperienced colleague, or if borderline large lymph nodes were described on CT 
eher malignen Lymphomen und reaktiven Lymphknoten als soliden Tumoren [8, 41]. Bei unklarer peripherer Lymphadenopathie wird die weiterführende Thorax-Röntgen-Aufnahme und/oder Körperstamm-CT im Falle der Sarkoidose häufig aufgrund des typischen Befallsmusters (asymptomatische bihiläre Lymphadenopathie, mit oder ohne symmetrischem Lungenbefall) die Verdachtsdiagnose in die korrekte Richtung lenken. Die Diagnosesicherung der Sarkoidose erfolgt klinisch, laborchemisch, radiologisch und bioptisch, wobei die definitive Unterscheidung gegenüber der wichtigen Differenzialdiagnose dem malignen Lymphom nur histologisch möglich ist [8]. Die periphere Lymphadenopathie bei Sarkoidose wird gerne für die bioptische Diagnosesicherung mittels offener Probeexzision oder ultraschallgezielter Stanzbiopsie genutzt [40].

\section{Tuberkulose}

Die hilären und mediastinalen Lymphknoten sind bei Tuberkulosebefall der Lunge, die mit etwa $80 \%$ das am häufigsten erkrankte Organ darstellt, meist mitbetroffen. Der Befall der peripheren Lymphknotenstationen ist deutlich seltener, wobei dabei bevorzugt der Hals, die Klavikularegion und die Axilla betroffen sind. Die Lymphknotentuberkulose neigt besonders zur Ausbildung von Nekrosen, liquiden Anteilen, Verkalkungen, Kapselüberschreitung und Fistelbildung [42]. Dementsprechend stark verändert erscheint häufig die sonografische Lymphknotenarchitektur und das farb/ powerdopplersonografische Bild ( $\bullet$ Abb. 11) [6, 32, 43]. Als relativ tuberkulosespezifisch können Verkalkungen und Fisteln gelten ( $\mathbf{A}$ Abb. 11) [35, 42]. Im Gegensatz zur Tuberkulose sind Lymphknotenverkalkungen bei Entzündungen anderer Genese und malignen Erkrankungen primär sehr selten und manchmal nach Chemo/Strahlentherapie nachzuweisen [14, 32]. Ausnahmen sind das papilläre und medulläre Schilddrüsenkarzinom, bei denen multiple punktförmige Verkalkungen in den befallenen Lymphknoten häufig vorkommen $[32,35]$.

Im Falle einer peripheren Lymphadenopathie wird die obligate Durchuntersuchung inklusive ThoraxRöntgen-Aufnahme und Körperstamm-CT, vor allem durch den typischen Lungenbefall der Tuberkulose, häufig diagnostisch richtungsweisend sein.

\section{Morbus Castleman}

Der Morbus Castleman ist eine seltene Lymphknotenerkrankung unbekannter Genese, die meist abdominale, mediastinale oder periphere Lymphknoten betrifft. Zwei Formen werden unterschieden: die häufigere lokalisierte Form (etwa 90\% der Fälle, histologisch meist hyaliner-vaskulärer Typ), bei der nur ein Lymphknoten befallen ist und die seltenere multizentrische Form (etwa 10\% der Fälle, histologisch meist plasmazellreicher Typ), bei der mehrere Lymphknoten betroffen sind. Die lokalisierte Form, die meist klinisch stumm verläuft, hat eine wesent- lich bessere Prognose als die multizentrische Form, die immer mit Beschwerden einhergeht.

Der/die Lymphknoten sind mäßiggradig bis deutlich vergrößert und erscheinen sonografisch meist homogen strukturiert [44]. Farb/Powerdopplersonografisch ist die Vaskularisation oft gesteigert und der Gefäßbaum unauffällig bis verändert. Das sonografische Erscheinungsbild ist unspezifisch und ähnelt häufig malignen Lymphomen und reaktiven Lymphknoten ( $\bullet$ Abb. 12) [44]. Die Diagnose erfolgt histopathologisch mittels offener Exzision oder Stanzbiopsie. Die Therapie der Wahl bei der lokalisierten Form ist die vollständige chirurgische Entfernung des betroffenen Lymphknotens, die in etwa $90 \%$ der Fälle zur Heilung führt.

\section{Beispiele seltener Entitäten}

Im Rahmen der Katzenkratzkrankheit, der Toxoplasmose, der Rosai-Dorfman-Erkrankung, der Kimura- oder der Kikuchi-Krankheit treten häufig vergrößerte periphere Lymphknoten klinisch in Erscheinung. Bei der Katzenkratzkrankheit, einer meist selbstlimitierenden Infektion durch das Bakterium Bartonella henselae, das durch Kratz- oder Bissverletzungen der Katze in die Haut eintritt, sind die Lymphknoten des Lymphabflussgebietes der Eintrittspforte (meist Axilla, Hals oder Ellenbeuge) betroffen [45]. Auch die Rosai-Dorfman-Erkrankung ist meist ein gutartig verlaufender Prozess jedoch unklarer Genese, bei dem es zu einer deutlichen Lymphknotenschwellung am Hals vor allem jugendlicher Patienten kommt [47]. Die Kimura-Krankheit und die Kikuchi-Krankheit sind ebenfalls meist selbstlimitierende Erkrankungen unklarer Genese bei Südostasiaten, die mit einer Lymphadenopathie am Hals einhergehen [46, 47]. Die befallenen Lymphknoten der genannten Entitäten sind im Allgemeinen gering bis mäßiggradig vergrößert. Die sonografische Lymphknotenarchitektur und das Vaskularisationsmuster sind oft erhalten oder seltener verändert. Die wichtigsten Differenzialdiagnosen sind gewöhnliche Entzündungen und das maligne Lymphom [45-47). Die sonografischen Erscheinungsbilder erlauben meist keine sichere Differenzierung, weshalb die Diagnosen klinisch, laborchemisch oder bioptisch gestellt werden müssen.

\section{Virchow Lymphknoten}

Eine interessante Besonderheit stellt der Befall des Virchow-Lymphknotens links supraklavikulär im Venenwinkel dar. Ein nicht schmerzhafter Tastbefund in diesem Bereich ist gelegentlich die klinische Erstmanifestation einer malignen Erkrankung. Die Metastasierung erfolgt über den Ductus thoracicus und ist gelegentlich beim Pankreaskarzinom, Magenkarzinom, oder generell bei ausgedehnten Malignomen des Bauchraumes und des Retroperitoneums zu beobachten ( $\bullet$ Abb. 6). Wichtig ist, dass der Untersucher diesen besonderen Ausbreitungsweg und dieses Befallsmuster kennt und gegebenenfalls eine ergänzende, gezielte Untersuchung

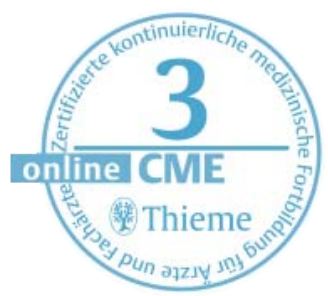



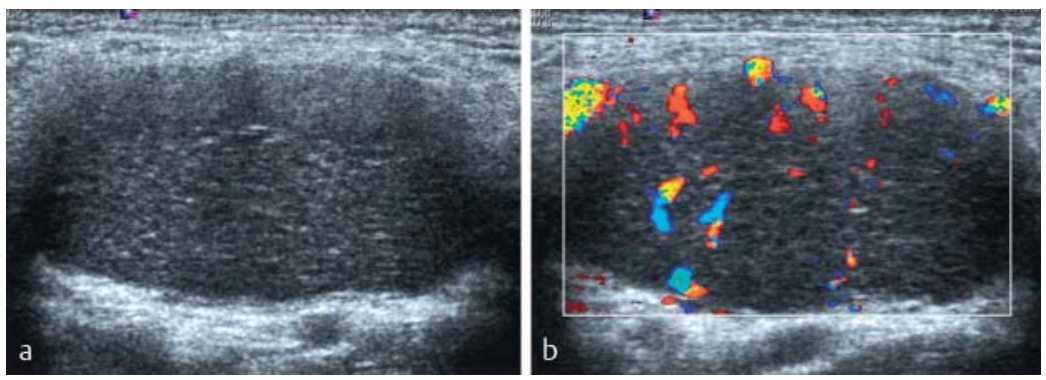

Fig. 12 Unilocular manifestation of Castleman disease with a left-sided supraclavicular location in a 24-year-old male patient. a shows a longitudinal section of the significantly enlarged lymph node (short-axis diameter of $21 \mathrm{~mm}$ ) with lack of sonographic lymph node architecture. The internal structure is relatively homogeneous with a speckled internal structure as often seen in malignant lymphomas. b shows the color Doppler sonographic image of the lymph node (7.3 MHz, 900 PRF, 50 WF) with peripherally intensified perfusion and a lack of the normal vascular tree emanating from the hilar region.

Abb. 12 Unilokuläre Manifestation eines Morbus Castleman bei 24-jährigem männlichen Patienten links supraklavikulär. a zeigt einen Längsschnitt des deutlich vergrößerten Lymphknotens (21 mm Kurzachsendurchmesser) mit aufgehobener sonografischer Lymphknotenarchitektur. Die Binnenstruktur ist relativ homogen mit getüpfelter Binnenstruktur, wie dies oft bei malignen Lymphomen zu beobachten ist. b zeigt die farbdopplersonografische Darstellung des Lymphknotens (7,3 MHz, 900 PRF, 50 WF) mit peripher betonter Durchblutung und Fehlen des normalen von hilär ausgehenden Gefäßbaumes.
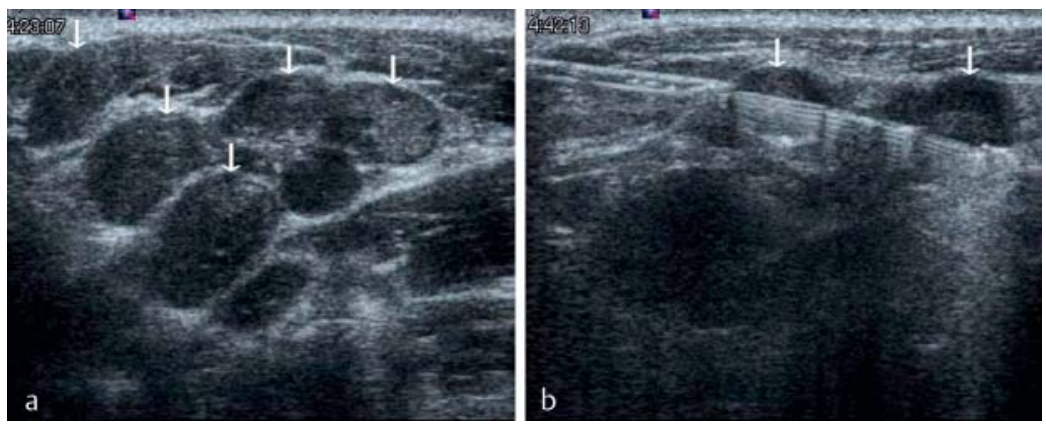

Fig. 13 Group of metastatic lymph nodes in the upper cervical region as a result of an undifferentiated carcinoma. The lymph nodes (arrows) are only slightly enlarged (short-axis diameter up to $8 \mathrm{~mm}$ ), have a clear border, and have a relatively homogeneous internal structure. b shows the diagnostic core biopsy ( $18 \mathrm{G}$, throw $2.2 \mathrm{~cm}$ ), with the semi-automatic biopsy needle taking samples from two lymph nodes at the same time.

Abb. 13 Gruppe metastatisch befallener Lymphknoten im oberen Halsbereich durch ein entdifferenziertes Karzinom. Die Lymphknoten (Pfeile) sind nur gering vergrößert (Kurzachsendurchmesser bis $8 \mathrm{~mm}$ ), scharf begrenzt und haben eine relativ homogene Binnenstruktur. b zeigt die diagnostische Stanzbiopsie (18 G, Vorschub 2,2 cm), wobei die Ausnehmung der halbautomatischen Biopsienadel gleichzeitig zwei Lymphknoten erfasst.

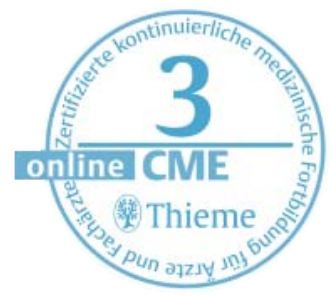

or MRI. However, this approach assumes that clinical suspicion of a disease requiring clarification does not necessitate further examinations.

In the case of borderline large lymph nodes or lymph nodes with a minimal increase in volume on both sides of the upper cervical region (punctum maximum jugulodigastric, regions Ib and II) and otherwise normal sonographic criteria, hyperplastic lymph nodes should be assumed particularly in young patients. Initial sonographic follow-up in 3 months is sufficient.

Borderline large or minimally enlarged lymph nodes with preservation of the remaining criteria in other regions without clinical evidence of a further disease requiring clarification should undergo sonographic follow-up, with the compari- son of the size (short-axis diameter) being the most important criterion. Sonographic follow-up at intervals of 3 months initially, then 6 months in the case of consistency of findings, and finally 1 year have proved successful.

Lymphadenopathies clinically and sonographically shown to be of an inflammatory origin should undergo sonographic follow-up in $3-4$ weeks particularly in serious cases even in the event of improvement of the symptoms in order to document complete retrogression.

In the case of reactive inguinal and/or axillary lymph nodes in wide-spread skin disease, dermatopathic lymph nodes should be assumed. Sonographic follow-up initially in 3 months is usually sufficient.

In lymphadenopathies that are clinically and/or sonographically suspicious for tumor, a thorough examination including $\mathrm{CT}$ of the torso should be performed to detect additional changes that can be seen via imaging and to determine the most suitable access for the usually necessary biopsy. In general, a commercially available ultrasound-guided $18 \mathrm{G}$ core biopsy needle (throw $2.2 \mathrm{~cm}$ ) should be used for this purpose ( $\bullet$ Fig.2). Multiple (usually 3) core biopsy specimens are typically taken to ensure sufficient material for histological examination. The core biopsy specimens are checked for quality immediately after removal. Specimens that disintegrate in formalin indicate extensive necrosis. When possible, more tissue samples should be taken to allow histological diagnosis. In the case of sufficiently large lymph nodes (larger than $2.5 \mathrm{~cm}$ ) and if structures to be avoided (vessels, nerves) are located distantly, a fully automatic needle can be used for core biopsy. In all other cases, a more accurately guidable semi-automatic needle should be used. In the case of small lymph nodes, a shorter needle throw must usually be used (e.g. from $2.2 \mathrm{~cm}$ to $1.5 \mathrm{~cm}$ depending on the manufacturer) [48].

Sonographically guided aspiration cytology can be performed on suspicious lymph nodes in the case of malignant ENT tumors for metastasis confirmation. However, core biopsy specimens provide more diagnostic information.

In the case of suspicion of a malignant lymphoma (based on imaging and clinical data), excisional biopsy of a lymph node for histological diagnosis should be performed if the node is easy to access via surgery. Sonography is used to select the most suitable lymph node (selection criteria: pathological presentation, good accessibility (superficial position, at a distance from important surrounding structures (large vessels, nerves)), favorable position of the resulting scar (e.g., axillary)). In the case of good palpability of the lymph node selected for surgical extirpation, a skin pencil can be used for marking. Otherwise, marking must be performed preoperatively using hook wire under ultrasound guidance to ensure reliable removal of the most pathological lymph node. In the case 
des Bauchraumes und des Retroperitoneums anschließt. Eine zusätzliche Körperstamm-CT gibt einen besseren Überblick über die bildgebend zu erfassenden morphologischen Veränderungen in den sonografisch nicht oder schwer zugänglichen Regionen wie Thoraxraum und Retroperitoneum.

\section{Weitere Vorgangsweise in Abhängigkeit vom sonografischen Befund}

Bei unauffälligem sonografischen Befund unter Berücksichtigung der in Teil 1 beschriebenen BBild-Kriterien und der farb/powerdopplersonografischen Kriterien ist keine weitere Diagnostik notwendig, wenn die Sonografie beispielsweise wegen eines unklaren Tastbefundes erfolgte, wenn ein wenig mit der Methode vertrauter Kollege zuvor einen unklaren sonografischen Lymphknotenbefund erhob, oder wenn in der CT oder MRT grenzwertig große Lymphknoten beschrieben wurden. Diese Vorgangsweise setzt aber voraus, dass nicht der klinische Verdacht auf eine abklärungsbedürftige Erkrankung weitere Untersuchungen notwendig macht.

Bei grenzwertig großen oder geringgradig volumsvermehrten Lymphknoten beidseits im oberen Halsbereich (punctum maximum jugulodigastrisch, Regio Ib und II) und ansonsten unauffälligen sonografischen Kriterien ist insbesondere bei jungen Patienten von hyperplastischen Lymphknoten auszugehen. Eine sonografische Verlaufskontrolle zunächst in 3 Monaten ist ausreichend.

Grenzwertig große oder gering vergrößerte Lymphknoten bei erhaltenen übrigen Kriterien in anderen Regionen ohne klinischen Hinweis auf eine weiter abklärungsbedürftige Erkrankung sollten sonografisch verlaufskontrolliert werden, wobei der Vergleich der Größe (Kurzachsendurchmesser) das wichtigste Kriterium darstellt. Sonografische Kontrollen in Intervallen von zunächst 3 Monaten, bei Befundkonstanz in weiteren 6 Monaten und danach nach einem weiteren Jahr haben sich bewährt.

Lymphadenopathien, bei denen das klinische und sonografische Bild für eine entzündliche Genese sprechen, sollten insbesondere in ausgeprägten Fällen auch bei Besserung der Symptomatik in 3 4 Wochen sonografisch kontrolliert werden, um eine vollständige Rückbildung zu dokumentieren. Bei reaktiv imponierenden Lymphknoten inguinal und/oder axillär bei großflächiger Hauterkrankung ist von dermopathischen Lymphknoten auszugehen, eine sonografische Kontrolle zunächst in 3 Monaten wird meist ausreichen.

Bei Lymphadenopathien die klinisch und/oder sonografisch tumorsuspekt erscheinen, sollte einerseits eine Durchuntersuchung inklusive Körperstamm-CT erfolgen, um weitere, mittels Bildgebung fassbare Veränderungen zu detektieren und andererseits den am besten geeigneten Zugangsweg für die meist notwendige bioptische Abklärung zu bestimmen. Generell sollte dabei eine ultraschallgeführte, handelsübliche 18 G Stanz- biopsienadel (Vorschub 2,2 cm) zur Anwendung kommen ( $\bullet$ Abb. 2). Normalerweise werden mehrere (meist 3) Stanzbiopsiezylinder entnommen, um ausreichend Material für die histologische Untersuchung zu erhalten. Die Stanzzylinder werden unmittelbar nach der Entnahme auf ihre Qualität geprüft. In Formalin zerfallende Zylinder sprechen für ausgedehnte nekrotische Anteile, wenn möglich sollten dann mehr Gewebszylinder entnommen werden, um eine histologische Diagnose zu ermöglichen. Bei ausreichend großen Lymphknoten (größer 2,5 cm) und wenn zu meidende Strukturen (Gefäße, Nerven) davon entfernt liegen, kann eine Vollautomatiknadel zur Stanzbiopsie verwendet werden. In allen übrigen Fällen sollte eine gezielter zu führende Halbautomatiknadel Verwendung finden. Bei kleinen Lymphknoten muss meist auf einen kürzeren Nadelvorschub zurückgegangen werden (je nach Fabrikat beispielsweise von $2,2 \mathrm{~cm}$ auf $1,5 \mathrm{~cm}$ ) [48].

Eine sonografisch geführte Aspirationszytologie kann an suspekten Lymphknoten bei malignen HNO-Tumoren zum Metastasennachweis erfolgen. Aussagekräftiger sind allerdings Stanzbiopsate. Bei Verdacht auf ein malignes Lymphom (bildgebungsmäßig und klinisch) sollte bei operativ guter Zugänglichkeit die offene Probeexzision eines Lymphknotens für die histologische Diagnose erfolgen. Die Sonografie dient dabei der Auswahl des am besten geeigneten Lymphknotens (Auswahlkriterien: möglichst pathologisches Erscheinungsbild, gute Zugänglichkeit [oberflächliche Lage, Distanz von wichtigen Umgebungsstrukturen (große Gefäße, Nerven)], günstige Lage der zu erwartenden Narbe [z.B.: axillär]). Bei guter Tastbarkeit des zur operativen Extirpation ausgewählten Lymphknotens kann mittels Hautstiftes markiert werden, ansonsten muss präoperativ regelhaft ultraschallgezielt mittels Hakendrahtes markiert werden, um die sichere Entnahme des auffälligsten Lymphknotens zu gewährleisten. Bei schwieriger operativer Zugänglichkeit, ausgedehnten Befunden und Konglomerattumoren ist der ultraschallgezielten Stanzbiopsie der Vorzug zu geben, da postoperativ das Risiko von ausgedehnten Hämatomen, Seromen und Lymphfisteln deutlich erhöht ist. Wenn es die Sicherheit des Zugangsweges erlaubt, sollte dabei die kaliberstärkere 16 G Stanzbiopsienadel verwendet werden und mehrere Biopsate (beispielsweise 5) entnommen werden [21, 48, 49]. Dies ermöglicht meist die notwendige Subklassifizierung der malignen Lymphome [8, 21, 48, 50, 51]. In Einzelfällen ist das Stanzbiopsiematerial zur Lymphomdiagnostik nicht ausreichend, sodass danach noch eine offene Probeexzision vorgenommen werden muss [8, 21, 48].

Lymphadenopathien bei bekannter CLL werden meist nicht histologisch bestätigt, es sei denn, dass der Verdacht auf eine Transformation in ein anderes malignes Lymphom vorliegt.

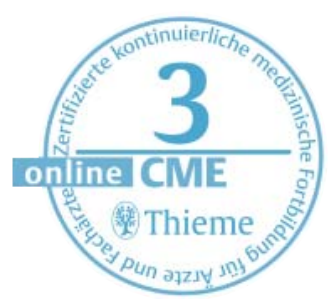


of limited accessibility for surgery, extensive findings, and conglomerate tumors, ultrasoundguided core biopsy is preferred since the postoperative risk of extensive hematomas, seromas, and lymphatic fistulas is significantly greater. If the access path allows, a higher caliber $16 \mathrm{G}$ core biopsy needle should be used and multiple biopsy specimens (e.g., 5) should be taken [21, 48, 49]. This usually makes it possible to perform the necessary subclassification of malignant lymphomas $[8,21,48,50,51]$. In individual cases, the core biopsy material is not sufficient for diagnosing lymphoma so that excisional biopsy must be subsequently performed $[8,21,48]$.

Lymphadenopathies in known CLL are usually not histologically confirmed unless transformation into another malignant lymphoma is suspected. Solitary findings that are suspicious for tumor and are surgically easy to be accessed should be completely removed without prior biopsy to prevent possible tumor cell spreading during biopsy.

\section{Final comments}

Three questions must be answered regarding the sonographic examination of peripheral lymph node stations: First: Is an identified structure a lymph node or something else? Second: In the case of a lymph node, is it normal or pathological? Third: If the lymph node appears pathological, is it possible to make a differential diagnosis and a classification according to the main groups: hyperplastic, inflammatory, or neoplastic? [26]. The answer to the second question is particularly important. Knowledge of the normal findings and their variability is a decisive foundation and is therefore described in detail in Part 1 [1]. The fact that the diagnostically important hyperechoic hilum of the cervical lymph nodes is often missing, the hyperechoic hilum of the axillary and inguinal lymph nodes can appear relatively hypoechoic, and lymph nodes are often rounded in some subregions of the neck are emphasized here as important but often little known features [1].

The individual sonographic criteria that have proven successful in the daily routine are described in detail in Part 1 [1]. In particular, these are the short-axis diameter, the cortex (cortical width and uniformity of the cortical width), homogeneity of the internal structure, and the vascular tree.

If lymph nodes appear pathological, the ultrasound diagnostician should help to determine whether a sonographic follow-up should be performed in 3-4 weeks in the case of suspicion of an inflammatory change, further examination and ultrasound-guided biopsy should be performed in the case of sonographic suspicion of neoplasia, or excisional biopsy should be recommended. The clinical history including the duration of the existence of a palpation finding and the evaluation of spontaneous pain and pain on palpation must be taken into consideration.

A general strength of sonography is the ability to perform compartment determination and differential diagnosis of palpable changes and in the case of appropriate experience, it allows various visual diagnoses, such as lymph node, cyst, vascular pathology, lipoma, glomus tumor, atheroma, salivary gland or thyroid gland pathology.

CT and MRI allow a better overview of extensive findings and deep-seated regions and better visualize distribution patterns of pathological lymph nodes and extranodal findings in the entire body than sonography. However, sonography is better suited for targeted evaluation of peripheral lymph nodes due to the good sonographic accessibility of these regions, the higher spatial resolution, and the good soft tissue discrimination and is therefore the imaging method of choice in such cases.

\section{Main statements}

Inflammatory reactive lymph nodes show an intensified normal vascular tree emanating from the central-hilar region on color/power Doppler sonography.

Color/power Doppler sonographic criteria of malignant lymph nodes in contrast to inflammatory reactive lymph nodes include asymmetry of the normal vascular tree, circumscribed negative areas and hypervascularized areas, a spotted vascular pattern, peripheral vascularization enhancement, and vessels with extracapsular extension.

Signs of inflammatory reactive lymph nodes are uniform widening of the hypoechoic lymph node cortex, increase in the short-axis diameter, uniform narrowing of the hyperechoic hilum (preserved sonographic lymph node architecture), and preserved vascular tree with slightly to significantly increased vascularization.

The often significant homogeneous hypoechoic volume increase of the lymph nodes with or without preservation of the sonographic architecture and increase of the vascularization with or without preservation of the original vascular tree is indicative of malignant lymphoma.

Lymph node metastases of solid tumors usually greatly change the sonographic lymph node architecture. Typical signs are the usually significant volume increase, the often pronounced inhomogeneous internal structure, the eccentric widening of the cortex, necrotic zones, and a greatly altered vascular pattern.

Affected lymph nodes in sarcoidosis often resemble malignant lymphomas or inflammatory reactive lymph nodes.

Diseased lymph nodes in tuberculosis often exhibit calcifications, liquid areas, and fistulas into the surroundings (e.g. to the skin). 
Solitäre tumorsuspekte Befunde, die operativ leicht zugänglich sind, sollten ohne vorherige bioptische Abklärung in toto entfernt werden, um eine mögliche Tumorzellverschleppung im Rahmen der Biopsie zu vermeiden.

\section{Abschließende Bemerkungen \\ $\nabla$}

Im Rahmen der sonografischen Untersuchung der peripheren Lymphknotenstationen gilt es vor allem drei Fragen zu beantworten: Erstens, handelt es sich bei einer identifizierten Struktur um einen Lymphknoten oder etwas Anderes? Zweitens, wenn es sich um einen Lymphknoten handelt, ist dieser als normal oder pathologisch zu interpretieren? Drittens, wenn dieser pathologisch erscheint, ist eine differenzialdiagnostische Eingrenzung und Zuordnung zu den Hauptgruppen: hyperplastisch, entzündlich oder neoplastisch möglich? [26]. Die Beantwortung der zweiten Frage ist besonders wichtig. Dabei ist die Kenntnis der Normalbefunde und deren Variabilität entscheidende Grundlage und in Teil 1 deshalb ausführlich beschrieben [1]. Dass der diagnostisch wichtige echoreiche Hilus an den Halslymphknoten oft fehlt, dass der echoreiche Hilus axillär und inguinal relativ echoarm erscheinen kann und, dass in einigen Subregionen des Halses Lymphknoten oft rundlich sind, seien hier als wichtige, oft wenig bekannte Gegebenheiten hervorgehoben [1].

Breiter Raum ist in Teil 1 den einzelnen sonografischen Kriterien gewidmet, die sich in der täglichen Patientenarbeit bewähren [1]. Diese sind insbesondere der Kurzachsendurchmesser, der Kortex (Kortexbreite und Gleichmäßigkeit der Kortexbreite), die Homogenität der Binnenstruktur und der Gefäßbaum.

Wenn Lymphknoten pathologisch erscheinen, sollte der Ultraschalldiagnostiker die weitere Vorgangsweise beeinflussen, ob im Falle des Verdachts einer entzündlichen Veränderung eine sonografische Verlaufskontrolle in 3-4 Wochen oder bei sonografischem Verdacht auf eine Neoplasie weiter durchuntersucht und sonografisch gezielt biopsiert werden sollte, oder zu einer offenen Probeexzision geraten werden muss. Dabei ist der klinische Hintergrund einschließlich der Frage nach der Dauer des Bestehens eines Tastbefundes und der Beurteilung der Spontan- und Druckschmerzhaftigkeit unbedingt zu berücksichtigen.

Eine Stärke der Sonografie liegt generell in der Kompartmentzuordnung und differenzialdiagnostischen Eingrenzung von tastbaren Veränderungen und erlaubt bei entsprechender Erfahrung verschiedene Blickdiagnosen wie Lymphknoten, Zyste, Gefäßpathologie, Lipom, Glomustumor, Atherom, Speicheldrüsen- oder Schilddrüsenpathologie.

Die CT und MRT erlauben eine übersichtlichere Darstellung von ausgedehnten Befunden und tiefliegenden Regionen und ermöglichen die bessere Darstellung von Verteilungsmustern pathologischer
Lymphknoten und extranodaler Befunde im gesamten Körper als die Sonografie. Zur gezielten Beurteilung der peripheren Lymphknoten ist die Sonografie wegen der guten sonografischen Zugänglichkeit dieser Regionen, der höheren Ortsauflösung und guten Weichteildiskriminierung aber besser geeignet und daher bildgebende Methode der Wahl.

\section{Hauptaussagen}

$\nabla$

Entzündlich reaktive Lymphknoten zeigen farboder powerdopplersonografisch eine Betonung des normalen, von zentral-hilär ausgehenden Gefäßbaumes.

Farb/powerdopplersonografhische Kriterien von malignen Lymphknoten im Gegensatz zu entzündlich reaktiven Lymphknoten umfassen Asymmetrien des normalen Gefäßbaumes, umschriebene Aussparungen und hypervaskularisierte Areale, das gesprenkelte (spotted) Gefäßbild, die periphere Betonung der Vaskularisation und kapselüberschreitende Gefäße.

Zeichen von entzündlich reaktiven Lymphknoten sind die gleichmäßige Verbreiterung des echoarmen Lymphknotenkortex, die Zunahme des Kurzachsendurchmessers, die gleichmäßige Einengung des echoreichen Hilus (erhaltene sonografische Lymphknotenarchitektur) und der erhaltene Gefäßbaum mit gering bis deutlich gesteigerter Vaskularisation.

Hinweisend für ein malignes Lymphom ist die oft deutliche homogene echoarme Volumszunahme der Lymphknoten mit oder ohne Erhalt der sonografischen Architektur und Zunahme der Vaskularisation mit oder ohne Erhalt des originären Gefäßbaumes.

Lymphknotenmetastasen solider Tumoren verändern meist stark die sonografische Lymphknotenarchitektur. Typische Zeichen sind die meist deutliche Volumszunahme, die oft ausgeprägt inhomogene Binnenstruktur, die exzentrische Kortexverbreiterung, Nekrosezonen und stark veränderte Gefäßmuster.

Befallene Lymphknoten bei Sarkoidose ähneln oft malignen Lymphomen oder entzündlich reaktiven Lymphknoten.

Erkrankte Lymphknoten bei Tuberkulose zeigen oft Verkalkungen, liquide Anteile und Fisteln in die Umgebung (z. B.: zur Haut).

In der sonografischen Verlaufskontrolle und Nachsorge einer Lymphadenopathie stellt der exakte Größenvergleich des voluminösesten Lymphknotens einer Region das wichtigste Kriterium dar. Dabei sollte der Kurzachsendurchmesser Anwendung finden.

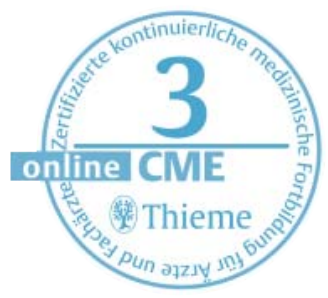


In the sonographic follow-up and aftercare of lymphadenopathy, an exact size comparison of the most voluminous lymph node of a region is the most important criterion. The short-axis diameter should be used for this purpose.

\section{Literatur}

1 Rettenbacher T. Sonographie der peripheren Lymphknoten Teil 1: Normalbefunde und B-Bild-Kriterien. Ultraschall in Med 2012; 31: 344-361

2 Delorme S. Sonographie vergrößerter zervikaler Lymphknoten. Bildgebung 1993; 60: 267-272

3 Tschammler A, Beer M, Hahn D. Differential diagnosis of lymphadenopathy: power Doppler vs color Doppler sonography. Eur Radiol 2002; 12: 1794-1799

4 Rubin JM, Bude RO, Carson PL et al. Power Doppler US: a potentially useful alternative to mean frequencybased color Doppler US. Radiology 1994; 190: 853 856

5 Sakaguchi T, Yamashita Y, Katahira K et al. Differential diagnosis of small round cervical lymph nodes: comparison of power Doppler US with contrast-enhanced CT and pathologic results. Radiation Medicine 2001; 19: 119-125

6 Na DG, Lim HK, Byun HS et al. Differential diagnosis of cervical lymphadenopathy: usefulness of color Doppler sonography. Am J Roentgenol 1997; 168: 1311-1316

7 Ying M, Ahuja A, Brook F et al. Power Doppler sonography of normal cervical lymph nodes. J Ultrasound Med 2000; 19: $511-517$

8 Gritzmann $N$, Hollerweger A, Macheiner P et al. Sonography of soft tissue masses of the neck. J Clin Ultrasound 2002; 30: 356-373

9 Tschammler A, Wirkner H, Ott G et al. Vascular patterns in reactive and malignant lymphadenopathy. Eur Radiol 1996; 6: 473-480

10 Esen G, Gurses B, Yilmaz MH et al. Gray scale and power Doppler US in the preoperative evaluation of axillary metastases in beast cancer patients with no palpable lymph node. Eur Radiol 2005; 15: 1215 1223

11 Moore A, Hester M, Nam MW et al. Distinct lymph nodal sonographic characteristics in breast cancer patients at high risk for axillary metastases correlate with the final axillary stage. Br J Radiol 2008; 81: 630-636

12 Giovagnorio F, Caiazzo R, Avitto A. Evaluation of vascular patterns of cervical lymph nodes with power Doppler sonography. J Clin Ultrasound 1997; 25: $71-76$

13 Tschammler A, Gunzer U, Reinhart E et al. Dignitätsbeurteilung vergrößerter Lymphknoten durch qualitative und semiquantitative Auswertung der Lymphknotenperfusion mit der farbkodierten Duplexsonographie. Fortschr Röntgenstr 1991; 154: 414-418

14 Esen G. Ultrasound of superficial lymph nodes. Eur J Radiol 2006; 58: 345 - 359

15 Brnic Z, Hebrang $A$. Usefulness of Doppler waveform analysis in differential diagnosis of cervical lymphadenopathy. Eur Radiol 2003; 13: 175-180

16 Hollerweger A, Rettenbacher T, Macheiner P et al. New signs of breast cancer: high resistance flow and variations in resistive indices. Evaluation by color Doppler sonography. Ultrasound Med Biol 1997; 23: 851 856

17 Choi MY, Lee JW, Jang KJ. Distinction between benign and malignant causes of cervical, axillary, and inguinal lymphadenopathy: value of Doppler spectral waveform analysis. Am J Roentgenol 1995; 165: 981-984
18 Steppan I, Reimer D, Müller-Holzner E et al. Breast cancer in women: evaluation of benign and malignant axillary lymph nodes with contrast-enhanced ultrasound. Ultraschall in Med 2010; 31: 63-67

19 Rubaltelli L, Beltrame V, Tregnaghi A et al. Contrastenhanced ultrasound for characterizing lymph nodes with focal cortical thickening in patients with cutaneus melanoma. Am J Roentgenol 2011; 196: W8 W12

20 Piscaglia F, Nolsoe C, Dietrich CF et al. The EFSUMB guidelines and recommendations on the clinical practice of contrast enhanced ultrasound (CEUS): Update 2011 on non-hepatic applications. Ultraschall in Med 2012; 33: 33-59

21 Weskott HP. Ultraschall in der Diagnostik maligner Lymphome. Radiologe 2012; 52: 347-359

22 Lo WC, Cheng PW, Wang CT et al. Real-time ultrasound elastography: an assessment of enlarged cervical lymph nodes. Eur Radiol 2013, Epub

23 Alam F, Naito K, Horiguchi J et al. Accuracy of sonographic elastography in the differential diagnosis of enlarged cervical lymph nodes: comparison with conventional B-mode sonography. Am J Roentgenol 2008; 191: 604-610

24 Choi JJ, Kang BJ, Kim SH et al. Role of sonographic elastography in the differential diagnosis of axillary lymph nodes in breast cancer. J Ultrasound Med 2011; 30: 429-436

25 Hinz T, Hoeller T, Wenzel J et al. Real-time tissue elastography as promising diagnostic tool for diagnosis of lymph node metastases in patients with malignant melanoma: a prospective single-center experience. Dermatology 2013; 226: 81 -90

26 Cosgrove D, Piscaglia F, Bamber J et al. EFSUMB guidelines and recommendations on the clinical use of ultrasound elastography. Part 2: clinical applications. Ultraschall in Med 2013; 34: 238-253

$27 \mathrm{Xu}$ W, Shi J, Zeng $X$ et al. EUS elastography for the differentiation of benign and malignant lymph nodes: a meta-analysis. Gastrointest Endosc 2011; 74: 1001 1009

28 Vassallo P, Edel G, Roos $\mathrm{N}$ et al. In-vitro high-resolution ultrasonography of benign and malignant lymph nodes. Invest Radiol 1993; 28: 698 - 705

29 Westhoff TH, Loddenkemper C, Hörl MP et al. Dermatopathic lymphadenopathy: a differential diagnosis of enlarged lymph nodes in uremic pruritus. Clin Nephrol 2006; 66: $472-475$

30 Majer MC, Hess CF, Kölbel G et al. Small arteries in peripheral lymph nodes: a specific US sign of lymphomatous involvement. Radiology 1988; 168: 241-243

31 Rubaltelli L, Proto E, Salmasco R et al. Sonography of abnormal lymph nodes in vitro: correlation of sonographic and histologic findings. Am J Roentgenol 1990; 155: 1241 - 1244

32 Ahuja A, Ying $M$. Sonography of neck lymph nodes. Part II: abnormal lymph nodes. Clin Radiol 2003; 58: 359-366

33 Hollerweger A, Macheiner P, Neureiter D et al. Außergewöhnlich zystisches Erscheinungsbild von Lymphknoten bei malignem Lymphom. Ultraschall in Med 2008; 29: $308-310$

34 King AD, Tse GMK, Ahuja A et al. Necrosis in metastatic neck nodes: diagnostic accuracy of CT, MR imaging, and US. Radiology 2004; 230: 720-726

35 Som PM. Lymph nodes of the neck. Radiology 1987; 165: 593-600

36 Steinkamp HJ, Beck A, Werk $M$ et al. Extracapsular spread of cervical lymph node metastases: diagnostic relevance of ultrasound examinations. Ultraschall in Med 2003; 24: $323-330$

37 Marone U, Catalano O, Caraco C et al. Can high-resolution ultrasound avoid the sentinel lymph-node biopsy procedure in the staging process of patients 
with stage I-II cutaneous melanoma? Ultraschall in Med 2012; 33: E179-E185

38 de Bondt RBJ, Nelemans PJ, Hofman PAM et al. Detection of lymph node metastases in head and neck cancer: a meta-analysis comparing US, USgFNAC, CT and MR imaging. Eur J Radiol 2007; 64: 266-272

39 Gruber I, Hahn M, Fehm T et al. Relevance and methods of interventional breast sonography in preoperative axillary lymph node staging. Ultraschall in Med 2012; 33: 337-343

40 Koyama T, Ueda $H$, Togashi $K$ et al. Radiologic manifestations of sarcoidosis in various organs. RadioGraphics 2004; 24: 87-104

41 Warshauer DM, Lee JKT. Imaging manifestations of abdominal sarcoidosis. Am J Roentgenol 2004; 182 : $15-28$

42 Haber HP, Warmann SW, Fuchs J. Cervical atypical mycobacterial lymphadenitis in childhood: findings on sonography. Ultraschall in Med 2006; 27: 462 466

43 Winkelbauer F, Denk DM, Ammann $M$ et al. Ultrasound diagnosis of cervical lymph node tuberculosis. Ultraschall in Med 1993; 14: 28-31

$44 \mathrm{Seo} B K, \mathrm{Oh} Y W$, Cho KR et al. Imaging findings of Castleman's disease localized in the axilla: a case report. Korean J Radiol 2002; 3: 136-139
45 Ridder GJ, Richter B, Disko U et al. Gray-scale sonographic evaluation of cervical lymphadenopathy in catscratch disease. J Clin Ultrasound 2001; 29: 140-145

46 Ahuja A, Ying M, MokJSW et al. Gray scale and power Doppler sonography in cases of Kimura disease. Am J Neuroradiol 2001; 22: 513-517

47 Ying M, Ahuja AT, Yuen HY. Grey-scale and power Doppler sonography of unusual cervical lymphadenopathy. Ultrasound Med Biol 2004; 30: 449-454

$48 \mathrm{Kim}$ BM, Kim EK, Kim MJ et al. Sonographically guided core needle biopsy of cervical lymphadenopathy in patients without known malignancy. J Ultrasound Med 2007; 26: 585-591

49 de Kerviler E, de Bazelaire C, Mounier $N$ et al. Imageguided core-needle biopsy of peripheral lymph nodes allows the diagnosis of lymphoma. Eur Radiol 2007; 17: $843-849$

50 Sklair-Levy M, Amir G, Spectre G et al. Image-guided cutting-edge-needle biopsy of peripheral lymph nodes and superficial masses for the diagnosis of lymphoma. J Comput Ass Tomogr 2005; 29: 369-372

51 Pfeiffer J, Kayser G, Ridder GJ. Sonography-assisted cutting needle biopsy in the head and neck for the diagnosis of lymphoma: can it replace lymph node extirpation? Larygoskope 2009; 119: 689-695 


\section{CME-Questions Sonography of Peripheral Lymph Nodes Part 2: Doppler Criteria and Typical Findings of Distinct Entities}

1

Which statement is correct?

A) Carcinoma metastases often significantly change the sonographic lymph node architecture.

B) The sonographic lymph node architecture is often not preserved in the case of hyperplastic and inflammatory reactive lymph nodes.

C) Squamous cell carcinoma particularly tends toward necroses and cystic areas with varying echogenicities.

D) Inflammatory reactive peripheral lymph nodes are often located in the lymphatic drainage area of the portal of entry of the pathogen.

E) Inflammatory reactive or hyperplastic lymph nodes can be assumed in the case of enlarged lymph nodes in the middle and lower cervical region.

A Only B-E are correct.

B Only A-D are correct.

C Only B-D are correct.

D Only A, C, and D are correct.

E Only B and D are correct.

Which statement regarding Doppler sonography of peripheral lymph nodes is false?

A To detect as many blood vessels as possible on color/power Doppler sonography, a low pulse repetition frequency (PRF) and wall filter (WF) setting is selected.

B In particular, normal lymph nodes exhibit central vascularization via the hilar vessels.

C Primarily solid tumors result in a significant change of the vascular tree.

D Deep-seated lymph nodes are often negative on color/ power Doppler sonography.

E Peripheral vascularization enhancement is a typical sign of benignity.

Which statement regarding Doppler sonography of peripheral lymph nodes is correct?

A) An increased resistance index ( $R I>0.8)$ is typical for vessels of malignant lymph nodes.

B) Inflammatory reactive lymph nodes usually have an intensified central vascular tree on color/power Doppler sonography.

C) The Doppler frequency must be increased to detect deep-seated vessels.

D) Normal probe pressure barely influences derived Doppler parameters in superficial lymph nodes.

E) Asymmetry in the vascular tree, negative areas, and peripheral vascularization enhancement are typical signs of benignity on color/power Doppler sonography.

A Only A-D are correct.

B Only A, B, and D are correct.

C Only A, D, and E are correct.

D Only B, C, and E are correct.

E Only A and B are correct.
Which statement is false?

A The normal sonographic lymph node architecture can be largely preserved in malignant lymphomas.

B Typical B-mode signs of malignant lymphomas are a hypoechoic, homogeneous internal structure, a uniform, hypoechoic, speckled internal structure, and enlarged lymph nodes strung together like a chain.

C Metastases with a size of less than $3 \mathrm{~mm}$ cannot be detected with any imaging method.

D Sonography often makes it possible to differentiate between different lymphoma subtypes.

E In the case of excisional biopsy of a peripheral lymph node for histological clarification, sonography is used to select the most suitable lymph node.

5 Which statement is correct?

A) Ultrasound-guided core biopsy is a useful supplement to sonography for further clarification of lymphadenopathy. B) In the case of chronic lymphocytic leukemia (CLL), the sonographic lymph node architecture is often preserved. C) The sonographic lymph node architecture is usually preserved in tuberculosis.

D) Tuberculous lymph nodes often have calcifications.

E) In the case of suspicion of inflammatory reactive lymph nodes, a lymph node biopsy is usually performed for confirmation of the diagnosis.

A Only A, B, and D are correct.

B Only A-D are correct.

C Only A, D, and E are correct.

D Only B, C, and E are correct.

E Only A-C are correct.

6 Which statement is correct?

A) Lymph node involvement in sarcoidosis often resembles malignant lymphomas and inflammatory reactive lymph nodes.

B) Involvement of Virchow's lymph node in the neck is only possible in the case of gastric carcinoma and pancreatic carcinoma.

C) Affected lymph nodes in malignant lymphoma are rarely calcified.

D) Sonography makes it possible to rule out lymph node metastasis in the lymphatic drainage area.

E) Affected lymph nodes in the case of malignant lymphoma rarely have cystic areas.

A All are correct.

B Only A-D are correct.

C Only A, D, and $\mathrm{E}$ are correct.

D Only B, C, and E are correct.

E Only A, C, and E are correct. 


\section{Which statement is false?}

A Lymph nodes affected by solid tumors frequently result in an inhomogeneous internal structure.

B Color/power Doppler sonography requires a minimum blood flow velocity, a minimum vessel size, and a favorable vessel course for vessel detection.

C Biopsies with an $18 \mathrm{G}$ core biopsy needle are usually sufficient for histological clarification of lymphadenopathy, while an entire lymph node should be removed or biopsied with a thicker $16 \mathrm{G}$ needle in the case of suspicion of malignant lymphoma.

D Negative areas in lymph nodes correspond to necrotic zones on color/power Doppler sonography.

E A high resistance index (RI) in a lymph node vessel and different resistance indices (RI) in a single lymph node are malignancy criteria.

8 Which statement is correct?

A) Contrast-enhanced ultrasound and elastography are not recommended for use in peripheral lymph nodes in the current EFSUMB guidelines.

B) Doppler spectral analysis allows relatively reliable differentiation between inflammatory lymph nodes and malignant lymphomas.

C) Uniform widening of the hypoechoic lymph node cortex is typical for inflammatory lymph nodes and can also be encountered in malignant lymphomas.

D) In ultrasound-guided core biopsy, several core biopsy specimens should be taken to ensure a reliable histological diagnosis.

E) Tumorous involvement of a lymph node can be ruled out with sonography.

A All are correct.

B Only A-D are correct.

C Only A, D, and E are correct.

D Only B, C, and E are correct.

E Only A, C, and D are correct.

\section{Which statement is false?}

A Dermatopathic lymph nodes resemble inflammatory reactive lymph nodes on sonography.

B Lymph node metastases of squamous cell carcinoma are often centrally necrotic.

C The change of the size of a finding (short-axis diameter) is the most important criterion during sonographic followup of lymphadenopathy.

D Sarcoidosis exclusively affects the supraclavicular region, the infraclavicular region, or the axilla.

E Tuberculous lymph nodes tend toward necrosis, liquid areas, extracapsular extension, and fistula formation.

10 Which statement is correct?

A) Necrotic zones in lymph nodes are always anechoic. B) Highly malignant lymphomas tend toward extracapsular extension and extensive hypoechoic infiltrates.

C) Only one lymph node is affected in localized Castleman disease.

D) Fine-needle aspiration cytology is sufficient for diagnosing and subtyping malignant lymphomas.

E) Affected lymph nodes in malignant lymphoma often appear very hypoechoic.

A Only B, C, and E are correct.

B Only B-E are correct.

C Only C-E are correct.

D Only $\mathrm{C}$ and $\mathrm{E}$ are correct.

E Only A, C, and D are correct. 


\section{CME-Fragen Sonografie der peripheren Lymphknoten Teil 2: Doppler-Kriterien und typische Befunde bestimmter Entitäten}

1 Welche Aussage ist richtig?

A) Karzinommetastasen verändern die sonografische Lymphknotenarchitektur oft stark.

B) Bei hyperplastischen und entzündlich-reaktiven Lymphknoten ist die sonografische Lymphknotenarchitektur oft nicht erhalten.

C) Das Plattenepithelkarzinom neigt besonders zu Nekrosen und zystischen Anteilen unterschiedlicher Echogenität. D) Entzündlich reaktive periphere Lymphknoten finden sich häufig im Lymphabflussgebiet der Erregereintrittspforte.

E) Bei vergrößerten Lymphknoten im mittleren und unteren Halsbereich ist meist von entzündlich-reaktiven oder hyperplastischen Lymphknoten auszugehen.

A Nur B-E sind richtig.

B Nur A-D sind richtig.

C Nur B-D sind richtig.

D Nur A, C und D sind richtig.

E Nur B und D sind richtig.

Welche Aussage zur Dopplersonografie peripherer Lymphknoten ist falsch?

A Um farb/powerdopplersonografisch möglichst viele Blutgefäße zu detektieren wird die Pulsrepititionsfrequenz (PRF) und der Wandfilter (WF) niedrig gewählt.

B Normale Lymphknoten zeigen vor allem zentrale Vaskularisation über die Hilusgefäße.

c Vor allem solide Tumoren führen zu einer deutlichen Veränderung des Gefäßbaums.

D Tiefliegende Lymphknoten sind oft farb/powerdopplersonografisch negativ.

E Die periphere Betonung der Vaskularisation ist ein typisches Benignitätszeichen.

Welche Aussage zur Dopplersonografie peripherer Lymphknoten ist richtig?

A) Ein erhöhter Widerstandsindex(RI>0,8) ist typisch für Gefäße maligner Lymphknoten.

B) Entzündlich reaktive Lymphknoten haben farb/powerdopplersonografisch meist einen betonten zentralen Gefäßbaum.

C) Um tiefliegende Gefäße zu detektieren muss die Dopplerfrequenz erhöht werden.

D) Normaler Druck mit dem Schallkopf kann abgeleitete Dopplerparameter oberflächlich gelegener Lymphknoten kaum beeinflussen.

E) Asymmetrien im Gefäßbaum, Aussparungen und die periphere Betonung der Vaskularisation sind typische farb/ powerdopplersonografische Benignitätszeichen.

A Nur A-D sind richtig.

B Nur A, B und D sind richtig.

C Nur A, D und E sind richtig.

D Nur B, C und E sind richtig.

E Nur A und B sind richtig.
A Bei malignen Lymphomen kann die normale sonografische Lymphknotenarchitektur weitgehend erhalten bleiben.

B Typische B-Bild-Zeichen für maligne Lymphome sind die echoarme homogene Binnenstruktur, die gleichmäßig echoarm-getüpfelte Binnenstruktur und das Bild der kettenartig aneinandergereihten vergrößerten Lymphknoten.

C Metastasen unter $3 \mathrm{~mm}$ Größe können mit keiner bildgebenden Methode nachgewiesen werden.

D Die Sonografie ermöglicht oft eine Unterscheidung der verschiedenen Lymphomsubtypen.

E Bei offener Probeexzision eines peripheren Lymphknotens zur histologischen Abklärung dient die Sonografie zur Auswahl des am besten geeigneten Lymphknotens.

5 Welche Aussage ist richtig?

A) Die sonografisch gezielte Stanzbiopsie ist eine sinnvolle Ergänzung der Sonografie zur weiteren Abklärung einer Lymphadenopathie.

B) Bei der chronischen lymphatischen Leukämie (CLL) ist die sonografische Lymphknotenarchitektur oft erhalten. C) Bei der Tuberkulose bleibt die sonografische Lymphknotenarchitektur meist erhalten.

D) Der tuberkulös befallene Lymphknoten weist oft Verkalkungen auf.

E) Bei Verdacht auf entzündlich reaktive Lymphknoten erfolgt meist eine Lymphknotenbiopsie zur Diagnosesicherung.

A Nur A, B und D sind richtig.

B Nur A-D sind richtig.

C Nur A, D und E sind richtig.

D Nur B, C und E sind richtig.

E Nur A-C sind richtig.

6 Welche Aussage ist richtig?

A) Der Lymphknotenbefall der Sarkoidose ähnelt oft malignen Lymphomen und entzündlich-reaktiven Lymphkoten. B) Der Befall des Virchow-Lymphknotens am Hals ist nur beim Magen- und Pankreaskarzinom möglich.

C) Befallene Lymphknoten bei malignem Lymphom sind sehr selten verkalkt.

D )Die Sonografie ermöglicht den Ausschluss einer Lymphknotenmetastase im Lymphabflussgebiet.

E) Befallene Lymphknoten bei malignem Lymphom haben selten zystische Anteile.

A Alle sind richtig.

B Nur A-D sind richtig.

C Nur A, D und E sind richtig.

D Nur B, C und E sind richtig.

E Nur $\mathrm{A}, \mathrm{C}$ und $\mathrm{E}$ sind richtig. 
A Der Lymphknotenbefall durch solide Tumoren verursacht häufig eine inhomogene Binnenstruktur.

B Die Farb/Powerdopplersonografie braucht zur Gefäßdetektion eine Blutflussmindestgeschwindigkeit, eine Gefäßmindestgröße und einen günstigen Gefäßverlauf.

c Zur histologischen Abklärung einer Lymphadenopathie reichen üblicherweise Biopsien einer 18 G Stanzbiopsienadel, bei Verdacht auf ein malignes Lymphom sollte allerdings ein gesamter Lymphknoten entnommen werden oder mit einer dickeren $16 \mathrm{G}$ Nadel biopsiert werden.

D Farb-/Powerdopplersonografisch negative Areale in Lymphknoten entsprechen Nekrosezonen.

E Ein hoher Widerstandsindex (RI) in einem Lymphknotengefäß und verschiedene Widerstandsindices (RI) in ein und demselben Lymphknoten gelten als Malignitätskriterien.

8 Welche Aussage ist richtig?

A) In den aktuellen EFSUMB Guidelines werden die Kontrastmittelsonografie und die Elastografie für den Einsatz an den peripheren Lymphknoten nicht empfohlen.

B) Die Dopplerspektralanalyse ermöglicht eine relativ verlässliche Unterscheidung zwischen entzündlichen Lymphknoten und malignen Lymphomen.

C) Eine gleichmäßige Verbreiterung des echoarmen Lymphknotenkortex ist typisch für entzündliche Lymphknoten und kann auch bei malignen Lymphomen anzutreffen sein.

D) Bei ultraschallgezielter Stanzbiopsie sollten mehrere Stanzzylinder entnommen werden, um eine verlässliche histologische Diagnose zu gewährleisten.

E) Mit der Sonografie kann ein tumoröser Befall eines Lymphknotens ausgeschlossen werden.

A Alle sind richtig.

B Nur A-D sind richtig.

C Nur A, D und E sind richtig.

D Nur B, C und E sind richtig.

E Nur A, C und D sind richtig.
9

A Dermopathische Lymphknoten ähneln sonografisch entzündlich-reaktiven Lymphknoten.

B Lymphknotenmetastasen des Plattenepithelkarzinoms sind zentral oft nekrotisch.

c Bei einer sonografischen Verlaufskontrolle einer Lymphadenopathie ist die Änderung der Größe eines Befundes (Kurzachsendurchmesser) das wichtigste sonografische Kriterium.

D Die Sarkoidose befällt ausschließlich die Supraklavikularregion, die Infraklavikularregion oder die Axilla.

E Tuberkulös befallene Lymphknoten neigen zu Nekrosen, liquiden Anteilen, Kapselüberschreitung und Fistelbildung.

10 Welche Aussage ist richtig?

A) Nekrosezonen in Lymphknoten sind immer echofrei. B) Hochmaligne Lymphome neigen zu Kapselüberschreitung und ausgedehnten echoarmen Infiltraten.

C) Bei der lokalisierten Form des Morbus Castleman ist nur ein Lymphknoten befallen.

D) Für die Diagnostik und Subtypisierung von malignen Lymphomen reicht die Feinnadelaspirationszytologie aus. E) Befallene Lymphknoten bei malignem Lymphom erscheinen oft sehr echoarm.

A Nur B, C und E sind richtig.

B Nur B-E sind richtig.

C Nur C-E sind richtig.

D Nur $\mathrm{C}$ und $\mathrm{E}$ sind richtig.

E Nur A, C und D sind richtig. 


\section{Continuing Medical Education (CME) - important note for readers outside Aus- tria, Germany and Switzerland $\nabla$}

At present, certification of the Continuing Medical Education features in Ultraschall in der Medizin/ European Journal of Ultrasound (UiM/EJU) is officially recognised by the German and Austrian medical associations and by the Swiss Ultrasound Society. Participants residing in other countries may please address their national medical association or their national specialist society for recognition of their CME scores.

Participation is possible via internet under http:// cme.thieme.com. For one Continuing Medical Education unit you will be credited with 3 score points. To be awarded this score, $70 \%$ of the questions must have been answered correctly. The $\mathrm{CME}$ unit in the present issue is available online for 12 months for CME participation.

CME participation for this article can be done online under http://cme.thieme.com.

\section{CME-Fortbildung mit Ultraschall in der Medizin}

Für Teilnehmer in Deutschland

Die Fortbildung in Ultraschall in der Medizin wurde von der Nordrheinischen Akademie für Ärztliche Fort- und Weiterbildung für das Fortbildungszertifikat anerkannt, das heißt, die Vergabe der Punkte kann direkt durch die Thieme Verlagsgruppe erfolgen. Die Fortbildung in Ultraschall in der Medizin gehört zur Kategorie „strukturierte interaktive Fortbildung“. Entsprechend einer Absprache der Ärztekammern werden die von der Nordrheinischen Akademie für Ärztliche Fort- und Weiterbildung anerkannten Fortbildungsveranstaltungen auch von den anderen zertifizierenden Ärztekammern anerkannt.

\section{Für Teilnehmer in Österreich}

Die Fortbildungspunkte der Ultraschall in der Medizin werden gemäß der Novellierung der DFPRichtlinien vom 23.6.2005 (§26 Abs.3) auch von den österreichischen Ärztekammern anerkannt.
Für Teilnehmer in der Schweiz

Die Fortbildungspunkte der Ultraschall in der Medizin werden gemäß der Richtlinien der SGUM/ SSUM anerkannt. Die Kontrolle der Fortbildung durch die SGUM/SSUM erfolgt im Auftrag der FMH (Foederation Medicorum Helveticorum) im Rahmen der Fortbildungsordnung.

\section{Datenschutz}

Ihre Daten werden ausschließlich für die Bearbeitung dieser Fortbildungseinheit verwendet. Es erfolgt keine Speicherung der Ergebnisse über die für die Bearbeitung der Fortbildungseinheit notwendige Zeit hinaus. Die Daten werden nach Versand der Testate anonymisiert. Namens- und Adressangaben dienen nur dem Versand der Testate. Die Angaben zur Person dienen nur statistischen Zwecken und werden von den Adressangaben getrennt and anonymisiert verarbeitet.

\section{Teilnahme}

Jede Ärztin und jeder Arzt soll das Fortbildungszertifikat erlangen können. Deshalb ist die Teilnahme am CME-Programm von Ultraschall in der Medizin nicht an ein Abonnement geknüpft! Die Teilnahme ist im Internet unter http://cme.thieme.de möglich. Im Internet muss man sich registrieren, wobei die Teilnahme an Fortbildungen abonnierter Zeitschriften ohne Zusatzkosten möglich ist. Die Fortbildungseinheit in diesem Heft ist 12 Monate online für eine CME-Teilnahme verfügbar.

\section{Teilnahmebedingungen}

Für eine Fortbildungseinheit erhalten Sie 3 Fortbildungspunkte im Rahmen des Fortbildungszertifikats. Hierfür müssen $70 \%$ der Fragen richtig beantwortet sein.

\section{CME-Fortbildung für Nicht-Abonnenten}

Teilnehmer, die nicht Abonnenten von Ultraschall in der Medizin sind, können für die Internet-Teilnahme dort direkt ein Guthaben einrichten, von dem pro Teilnahme ein Unkostenbeitrag abgebucht wird.

Die CME-Teilnahme für diesen Beitrag ist online möglich unter http://cme.thieme.de.
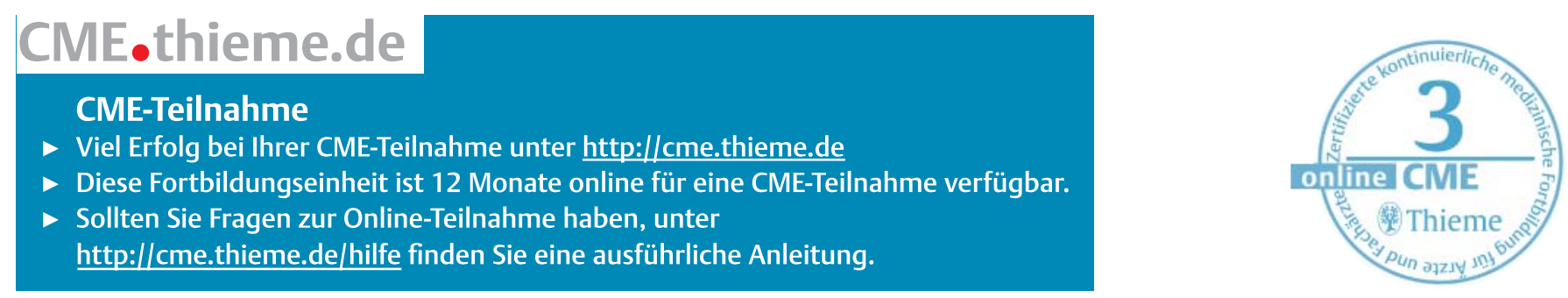